Please do not remove this page

RMIT

UNIVERSITY

\title{
Building a scale for dynamic learning capabilities: The role of resources, learning, competitive intent and routine patterning
}

Verreynne, Martie-Louise; Hine, Damian; Coote, Len; Parker, Rachel

https://researchrepository.rmit.edu.au/esploro/outputs/9921861497901341/filesAndLinks?institution=61RMIT_INST\&index=null

Verreynne, M.-L., Hine, D., Coote, L., \& Parker, R. (2016). Building a scale for dynamic learning capabilities: The role of resources, learning, competitive intent and routine patterning. Journal of Business Research, 69(10), 4287-4303. https://doi.org/10.1016/j.jbusres.2016.04.003

Document Version: Accepted Manuscript

Published Version: https://doi.org/10.1016/j.jbusres.2016.04.003

Repository homepage: https://researchrepository.rmit.edu.au

CC BY-NC-ND V4.0

(C) 2016 Elsevier Inc. All rights reserved

Downloaded On 2023/04/27 00:24:17 +1000 


\title{
Building a scale for dynamic learning capabilities: \\ The role of resources, learning, competitive intent and routine patterning
}

\begin{abstract}
Those researching organizational capabilities have largely accepted that the most fundamental operational capabilities form a hierarchy ranging from the lower-order dynamic functional to higherorder dynamic learning capabilities. Measurability has advantaged the first two types, resulting in numerous operationalized measurement scales. Yet at the strategic level, higher-order capabilities remain unmeasured, thus perpetuating issues of causal ambiguity. This paper responds by developing and presenting a measurement scale of dynamic learning capabilities (DLCs). Using multiple sources of data, we follow a five-step process to propose to measure and then validate a reliable scale consisting of three subscales. These subscales complement and thus extend the existing exploration and exploitation learning subscales. This predictive validity is further supported by relating all our subscales to perceived performance. Employing this dedicated new scale will enhance both the validity of studies on higher-order dynamic capabilities and the understanding of how firms create and use capabilities to drive performance.
\end{abstract}

Keywords: Dynamic learning capabilities, scale development, resources, routines, patterning, competitive intent 


\section{Building a scale for dynamic learning capabilities: The role of resources, learning, competitive intent and routine patterning}

\section{Introduction}

The research infrastructure supporting the field of organizational capabilities has been developed over the last two decades. Extensive early work undertaken into the taxonomies and definitions of the main concepts that underpin this field (Collis, 1994; Teece, Pisano, \& Shuen, 1997; Eisenhardt \& Martin, 2000) has been followed by an explication within many quality publications of the relationships between these concepts (e.g. Helfat \& Peteraf, 2003; Teece, 2007, Schilke, 2014; Karna, 2015). The field has also benefited from research that seeks to provide a comprehensive analytical framework that synthesizes the major concepts into a cohesive whole. This includes establishing and refining a hierarchy of capabilities, ranging from operating capabilities to both lower-order dynamic functional and higher-order dynamic learning capabilities (DLCs) (Ambrosini \& Bowman, 2009; Ambrosini, Bowman, \& Collier, 2009; Collis, 1994; Hine, Parker, Pregelj, \& Verreynne, 2014; Winter, 2003). As such, there is now convergence in how the broader capability field is conceptualized and a focus on measurement of different capability types is timely.

This is because for a field to progress from a view to a theory, conceptualization must be supported by empirical studies in a rigorous validation process (Barney, Ketchen, \& Wright, 2011). To date, theory development through empiricization within the dynamic capability field has largely focused on establishing methods for specific dynamic functional capabilities, such as internationalization (Mort, Weerawardena, \& Liesch, 2012), alliances (Rothaermel \& Hess, 2007), and marketing (Vorhies \& Morgan, 2005) [for a more comprehensive list of the diverse research directions see Barreto, 2010]. While functional measures are important, they only partially address the questions that researchers should ask. Hence, Ambrosini and Bowman's $(2009,36,43)$ observation that "few studies explore (a) whether capabilities always operate singly, (b) whether they can operate in combination, and (c) which dynamic capabilities might be more suitable, depending on each firm's situation". Measurability has advantaged the first two types of capabilities, 
resulting in numerous operationalized measurement scales. To illustrate, in a recent meta-analysis of the field, Karna, Richter and Riesenkampff (2015) were only able to find enough consistency in dynamic functional and operating capabilities to conduct a sufficiently robust analysis. Therefore, at the strategic level, the higher-order capabilities remain unmeasured, thus perpetuating issues of causal ambiguity. As Schilke $(2014,368)$ remarks: "there is a dearth of empirical work investigating the role of second-order dynamic capabilities". Therefore, to help advance dynamic capability theory validation, we require empirical studies that use capabilities from different levels of the capability hierarchy. Without dedicated measures for DLCs, the feasibility of such studies remains constrained and thus affects the rigour and legitimacy of the field.

Newer conceptualizations (e.g., Di Stefano, Peteraf, \& Verona, 2014; Teece, 2014) show that learning in itself is an insufficient measure of DLCs, and that resources, competitive intent and routines are crucial to detecting the presence and level of DLCs in firms. When measured, authors (e.g., Schilke, 2014) are moving past using learning as a measure, but still present measures that tend to focus on one aspect of strategic types, in this case alliances. Therefore, while theoretical convergence has occurred, measures at the higher end of the hierarchy have not progressed, and do not truly represent all aspects of the definition of higher order DLCs. It is this gap that our scale is designed to address. Piecing together existing scales designed for other purposes, as has been the practice in dynamic capabilities studies to date (see Danneels, 2008; Jansen, Van Den Bosch \& Volberda, 2006), may produce the desired outcomes. However, this developmental issue in which "arguably the most influential dynamic capabilities articles, those by Teece et al. (1997) and Eisenhardt and Martin (2000), use illustrative examples derived from data that, while pertinent, were not collected purposively to understand dynamic capabilities" (Ambrosini \& Bowman, 2009, 36), raises content validity issues. As a result the dynamic capability field would benefit from the dedicated development of fit-for-purpose scales focusing on the elements of the dynamic capability construct that have been hardest to measure and therefore define: higher-order DLCs. 
In this paper, we seek to develop a designed-for-purpose scale for DLCs. This is a challenging task because it requires a rigorous scale development process. We therefore take a mixed-methods approach in the design, development and validation of an appropriate scale by following the guidelines established by De Vellis (2012). The platform used to guide the development of this new scale is founded on the first phase: the extensive conceptual work that has sought to integrate the major concepts and relationships that underpin our understanding of dynamic capabilities (Ambrosini \& Bowman, 2009; Ambrosini et al. 2009; Hine et al., 2014; Teece, 2014). This forms the basis of new appropriately derived items that capture elements specific to higher-order DLCs. However, it would not be prudent to ignore the valuable work done by authors such as Jansen, et al. (2006) and others. Therefore, we also integrate existing scales that are both most cited and used in dynamic capabilities studies.

We proceed by describing the process that led to the self-report DLC scale being developed and validated. We explain our phased approach to developing the new scale, and briefly present the results of the exploratory process we undertook to understand the relationship between the microfoundations of capabilities, which are also regarded as their antecedents (Danneels, 2008; Teece, 2007), the environment that the firms operate within, and the capabilities that are evident in these firms. We then validate the new scale by using a series of empirical tests and by integrating results from our quantitative phase against the existing scales for their explanatory power as it relates to a dependent variable: performance. We conclude by discussing how the DLC scale can be used to advance the theoretical development of the dynamic capability field.

\section{Conceptualizing dynamic capabilities and dynamic learning capabilities}

It is generally accepted that dynamic capabilities are change-focused and thus act to create new resources, routines or operating capabilities (see Table 1 for definitions and examples). As such, dynamic capabilities have been conceptualized as a hierarchy (Collis, 1994; Winter, 2003), which has been extended to incorporate three levels of capabilities: operating capabilities, and lower and higher-order dynamic capabilities (Danneels, 2012; Hine, et al. 2014: Schilke, 2014). At the lower end 
of the hierarchy are ordinary/operating capabilities. These are non-change focused capabilities fundamental to the day-to-day workings of the firm. On the next level up in the hierarchy lie dynamic functional capabilities. They are change-focused capabilities, but are still directly responsible for firm outputs and performance in dynamic environments. These are created by learning mechanisms, which suggests that they are lower in the capability hierarchy. We therefore now more closely examine these higher- or second-order capabilities, which from now on we refer to as Dynamic Learning Capabilities (DLCs).

DLCs involve coordination, learning, and strategic competitive response activities that include new creatively and innovatively derived routines and resources (see Table 1). This is the level at which the greatest concerns about causal ambiguity exist (Collis, 1994). If dynamic capabilities affect resources (through modification, cannibalization, renewal, accumulation, or divestment), the most easily measured effects of DLCs will be on resources. Yet, according to the accepted definitions of operating capabilities, resources are used and are also affected by dynamic functional capabilities (Schilke, 2014). Further, dynamic functional capabilities are generally considered to be discernible and relatively easily captured, at least by proxy. Indeed, as previously indicated, most of the scale development work to date has focused on dynamic functional capabilities such as marketing, international and alliance formation.

Causal ambiguity stems from the dynamic capability being either one (dynamic functional capabilities) or two (DLCs) steps removed from the ordinary capabilities, and thus the resources they influence. Therefore, developing measurement scales for higher-order DLCs requires unravelling their micro-foundations and antecedents to understand how they are different from dynamic functional capabilities and operating capabilities. Given that they are so difficult to measure directly, part of the unravelling depends upon revealing the elements that reflect DLCs.

Understanding that dynamic capabilities are built rather than bought in the market (Makadok, 2001), and as a result become embedded in a firm (Eisenhardt \& Martin, 2000), means dynamic capabilities rely on an extensive learning process. For those within such a firm, learning from 
experience, but not experience alone, leads to building a stock of knowledge that itself needs to develop if it is to remain dynamic (Ambrosini \& Bowman, 2009). Path dependence is an accepted aspect of dynamic capabilities (Zollo \& Winter, 2002). However, capabilities must change to keep pace with environmental progress if they are to remain dynamic, or else they will become redundant and rusty owing to disuse (Winter, 2003). Over time, environmental dynamics will render each dynamic capability redundant. Therefore, former dynamic capabilities have the potential to cause problems for the firm by causing inertia (Szulanski, 2006), thereby worsening its competitive position. So we need to also take account of these as we test the capabilities of a firm.

But it is not only learning that is reflected in DLCs. Felin and Foss (2011) argue that, while the type of capability that a firm deploys depends on the environment's dynamism, its capabilities are influenced by how the firm develops routines and resources in response to this dynamism (Barreto, 2010). These authors argue that the empiricist assumptions of a blank slate and the experience created by response to external (usually social environmental) stimuli, which builds deterministically toward capabilities, fails to capture the dynamic capabilities' essence: dynamism itself (Felin \& Foss, 2011, p. 7). Their concern is that all explanatory power is given to experience and repetition as exogenous variables. They believe that, at least in part, capabilities are built on endogenous stimuli, in that intent and intentionality and, to a lesser extent, a learning focus, motivate capability development. This view is pervasive in the literature, with Teece (2014) for example arguing that the ability of managers to recognize trends and guide the firm to respond are crucial features of DLCs a surprisingly similar point to that of heuristics (see Eisenhardt \& Martin, 2000).

In a recent conceptual paper on the dynamic capabilities hierarchy, Hine, et al. (2014) summarizes these ideas to present an interdependent set of reflective dimensions designed to explain the structure and function of dynamic capabilities (as opposed to Barreto's $[2010,271]$ ) construct that regards dynamic capabilities as being 'formed by' their four dimensions). Hine, et al.'s framework contains an interdependent hierarchy of competitive intent, routines and resources that broadens the learning process from exploitation and exploration (Jansen et al., 2006). This 
conceptualization is reflected in more recent works such as Teece's (2014) that clearly identify the other aspects of DLCs, such as resources, competitive intent and routines. Indeed, in their argument for definitional integration between the Teece, and Eisenhardt and Martin camps, Di Stefano, et al. (2014) and Peteraf, Di Stefano, and Verona (2013) highlight these same four aspects of DLCs as crucial for the field as it moves forward. These newer conceptualizations suggest that additional content should be covered in a measure of DLCs, and that is what we seek to do. We therefore use this framework to guide our development of a scale to measure DLCs, as explained below.

We conclude this brief overview by reminding the reader that the raison d'être of capabilities is to enhance firm performance, which places the onus on testing the capabilities-performance relationship. However, as Hine et al. (2014) and Schilke (2014) argue, there is confusion about whether DLCs directly contribute to performance (Danneels, 2012; Macher \& Mowery, 2009), or whether this relationship is mediated by intermediate outputs such as innovation. For reasons of simplicity, we follow the first approach (Eisenhardt \& Martin, 2000) to argue that each of the constructs in our scale will be related to performance. That said, we do expect that there will be differences in how these constructs relate to different types of performance. We explain these differences in the discussion section.

\section{Scale development process}

In developing meaningful scales to test the constructs that create a foundation for analyzing dynamic capabilities unidimensionally, researchers have borrowed from closely related constructs such as antecedents to capabilities (from Danneels, 2008), and from beyond the field, such as, from the exploration/exploitation scale (see particularly Jansen et al. 2006). If we are seeking a universal theory of dynamic capabilities, then we require scales that work unidimensionally, meaning in a singular model. As explained earlier, we employ a reflective scale in that the extent of the existence of a dynamic capability is reflected in the scale.

DeVellis $(2012,12)$ defines a scale as consisting of “'effect indicators' - that is, items whose values are caused by an underlying construct (or latent variable)." We used the approach advocated 
by Bagozzi, Yi, and Phillips (1991), Cardon, Gregoire, Stevens, and Patel (2013), and DeVellis (2012) to develop our scale and subscales in five steps using data collected from four sources (see Table 2). First, we articulated our measurement strategy using the literature to identify existing scales and theoretically valid items. Second, we conducted a qualitative, interview based study $(n=110)$. Third, we sought expert opinion to help refine the scale $(n=8)$. Fourth, we tested the scale in a survey of 600 Australian firms. Last, we analyzed the data to refine and present the final DLC scale. These steps allowed us to examine the structural, nomonological and predictive validity of our scales. The first three steps depicted above involved pilot studies that enabled us to refine our survey before it was administered to a broader sample. These studies are described first.

Insert Table 2 here

\subsection{Literature survey and initial item pool}

Our literature review served two purposes. First, based on the work of Ambrosini and Bowman (2009) and supplemented by the theoretical model developed by Hine et al. (2014), we showed that DLCs consist of five sub-concepts. They are predominant resources, routine frequency, and competitive intent, as well as explorative and exploitative learning (see Table 2 for definitions of each). These sub-concepts were reiterated in the widely used definitions shown in Table 1.

We generated 29 items to address the first three sub-constructs, based on our definition of dynamic capabilities and a comprehensive review of the literature and the definitions and themes contained therein (e.g., Danneels, 2008; Jansen et al., 2006; Kale \& Singh, 2007; Marcus \& Anderson, 2006). Table 1 shows how we used our literature review, supported by the qualitative findings to identify a number of items that could potentially measure these sub-concepts (Nunnally, 1978). We chose to develop multi-item scales because they could reduce measurement error and provide a robust measure of complex variables such as those included in this study (Stratman \& Roth, 2002). 
At that point, we aimed for redundancy to maximize the content validity of the scale (Hogan, Soutar, McKoll-Kennedy, \& Sweeney, 2011). These items serve as a starting point for our item pool.

In our proposed scale, we also included 20 items from the existing scales to test explorative and exploitative learning (Jansen et al., 2006). These scales have been used extensively in the literature for this purpose (e.g., Alexiev, Jansen, Van den Bosch, \& Volberda, 2010; Camison \& Fores, 2010; Li \& Huang, 2012; Li, Zhou, \& Si, 2010; Oh, Teo, \& Sambamurthy, 2012; Tamayo-Torres, RuizMoreno, \& Llorens-Montes, 2011). These scales have obtained satisfactory reliability scores in a number of settings (e.g., manufacturing firms, general Chinese or Taiwanese firms, and Dutch small firm retailers). Each of the questions in our scale was structured so that respondents could express the extent to which they agreed with a positively phrased statement. This approach is used widely (e.g., Kale \& Singh, 2007; Marcus \& Anderson, 2006) and is consistent with the broader approach in the strategy literature to anchor items in 'strongly disagree' and 'strongly agree' (e.g., Danneels, 2008). It also fits our intention of using DLCs as firm enhancing constructs (Dixon, Meyer, \& Day, 2014).

\subsection{Design of Qualitative Study}

We conducted the literature survey iteratively with a large-scale qualitative study to identify and support the underlying themes of our sub-concepts. Interviews allowed us to gain an insight that was not otherwise available from survey approaches (Gwinner, Gremler, \& Bitner, 1998; Malhotra, Hall, Shaw, \& Oppenheim, 2002), thereby helping us to "uncover and understand what lies behind [a] phenomenon about which little is known" (Strauss \& Corbin, 1990, p. 19).

Similar to Hogan et al. (2011), we used a purposive sample at this stage to identify participants who would be able to inform us about our main scale development. Firms that participated in developmental programs were invited to be interviewed, based on their organizational learning processes that underpin their capability building. Participants were from industry sectors as diverse as manufacturing, farming, construction, information technology, and biotechnology; from metropolitan to regional and rural locations; and from a range of firm sizes from small to much 
larger firms. Interviews were held with the owners/managers of 110 of the 250 firms from these databases, assuming that these leaders would not only be critical players in capability building, but would also sufficiently inform us about the activities undertaken by the firm during the process (Shepherd \& DeTienne, 2005).

Because capabilities take time to develop, we interviewed those who had gone through each of the programs at least six months prior to interview. While this allowed for other extraneous variables to intervene, we were not seeking a direct correlation between what was undertaken in the program and the capabilities they had built. The initial interview protocol was based on the definitions and frameworks derived from the literature review, which included a number of broader questions that would allow other views to emerge. We collected data as we were analyzing the data already collected. This meant that data became increasingly focused, to the extent that we apparently reached theoretical saturation (Glaser \& Strauss, 2009) after about 30 interviews. However, we continued to interview most of the participants in the database to provide us with data for other purposes. Interviews were semi-structured and lasted between 45 and 75 minutes. The interviews were recorded, transcribed and returned to participants for their approval and to meet our ethical obligations.

\subsection{Data analysis and results for qualitative study}

To ensure that we did not impose the theoretical framework on our data, we took an interpretivist approach. This meant that we identified, interpreted and translated the elements of dynamic capabilities (Putnam, 1983) from our personal understanding of the experiences and activities of the interviewees, while taking into account the complexities and contexts relevant to the field (Eisenhardt \& Graebner, 2007). It also allowed a systematic approach to analysis wherein the results of research were viewed as individual interpretations of fact (Sandberg, 2001). We followed established procedures for the analysis of qualitative data (Miles \& Huberman, 1994) by undertaking an initial coding and identification of themes through relating our findings to the literature, and reanalyzing and recoding data in light of emerging patterns and the developing theory (Eisenhardt, 
1989). Table 2 shows how the results from the qualitative study relate to our starting point and the scale that formed part of our final survey. From our manual open coding, it soon became apparent that the concepts identified were highly correlated with those defined in the original theoretical model. At this stage, our analytical technique became focused on carefully comparing interviews, and seeking variations rather than recurring patterns of intermediary impacts.

The theoretical discussion distinguished between those firms operating in high velocity markets and those in lower velocity markets. Our results indicated that those firms that were operating in more stable environments had time to undertake extensive patterning, while innovation was less obvious than in high velocity markets. Given a predominance of general rather than specialized resources, and a reliance on codified rather than tacit knowledge of competitiveness, for most firms in lower velocity markets, lower-order capabilities dominated their strategic achievement.

\subsection{Expert opinion}

Based on the preceding stages, the pool of items was refined. Expert opinion from other researchers who are knowledgeable in this area further helped to eliminate any of our perceptual distortions. Experts were provided with our framework, definitions, and a list of the items pertaining to each construct. We used Zaichkowsky's (1985) rating method and suggestions to retain items if at least 80 percent of judges rated it as at least somewhat representative. Their feedback resulted in the refining of the wording of some items, as well as the elimination of seven items, leaving us with 22 items for further analysis.

\subsection{Final measures}

Combining the findings from the qualitative research with the literature review and the review of existing scales measuring similar constructs, we settled on the multifactor structure, similar to that shown in Table 2. We therefore operationalized our DLC scale as a second-order construct with five reflective dimensions (Cepeda \& Vera, 2007). This table shows that, although most aspects of DLCs were not covered in the scales we reviewed, items from scales pertaining to specific factors 
were used in some of the subscales of the DLC scale. Furthermore, two factors, explorative and exploitative learning, adopted scales developed and used in past studies (Jansen, et al., 2006). As these scales have been shown to be replicable with suitable validity and reliability in studies undertaken in certain contexts (e.g., Ren \& Guo, 2011), they were therefore included in our scale development process. Because all these factors share an underlying theme, it was expected that a common higher-order factor, namely DLC, would be present. For the same reason, we expected that the factors would be independent, but highly correlated. We therefore progressed to the next stage of the scale development process.

\section{Survey method}

To test our scales, we used telephone surveys with the CEOs/owners of Australian firms, conducted over a period of three and a half months. CEOs were targeted because they were putatively most knowledgeable of their firm's operations (Flatten, Engelen, Zahra, \& Brettel, 2011). The firms were randomly selected from the Impact list database, using a stratified approach that excluded farming operations, foreign-owned firms, and micro-firms. Micro-firms (i.e., fewer than three employees) were excluded because previous studies have shown that organizational processes do differ for very small firms (Gray, 2004; O’Regan \& Ghobadian, 2004). The phone surveys were conducted by a professional, academic survey institute, using highly skilled staff.

The final survey consisted of questions about demography, the DLC subscales, and perceived performance (Lebas \& Euske 2002; Li, Veliyath, \& Tan 2013; Lyon, Lumpkin, \& Dess 2000). Performance was included to test predictive validity. Respondents were asked to indicate their level of agreement on all items on a five point Likert scale that was anchored with 'strongly disagree' and 'strongly agree'. Higher scores meant that those items were used more, indicating a specific approach to DLCs. The order of the items of the DLC subscales was mixed. A total of 600 phone interviews were conducted, and the response rate was of 53 percent.

The firms in our stratified sample averaged 32 years old, with a median age of 22 years. Half employed fewer than 20 employees, with 43 percent employing more than 100 full-time employees. 
The sample thus represented the full range of firm sizes, ranging from 3 to 10,000 with a median firm size of 21 employees. Sixty nine percent of firms had international sales, with 11 percent deriving more than 10 percent of their sales from international markets. Industries were well presented, with between 10 and 15 percent of firms from each of the manufacturing, retail, accommodation/cafes and construction industries. Wholesale, transport/storage, communication, finance/insurance each had between five and 10 percent of the total firms.

\section{Results}

Our empirical analysis consists of four parts: First, we subject all 22 new items to an exploratory factor analysis. The purpose is to establish the dimensions of the new scale. Second, we fit one-factor models to each of the subscales of the DLC scale. This approach primarily seeks to establish the unidimensionality of each subscale. Third, we specify and test a multi-factor model (i.e., confirmatory or restrictive factor analysis) and some variations on it. Using these models, we can establish the convergent and divergent validity of the subscales and provide further evidence of item validity and reliability. Finally, we specify and estimate a series of full structural equations models that establish the predictive related validity of the new DLC scale.

\subsection{Descriptive Analysis}

The item means fell in the range of 3-3.5 on the 5-point response scales used. Standard deviations for the items fell in the range of one scale point. Thus, there is sufficient variation in the scale items to warrant further analysis. Furthermore, each of the survey items is normally distributed or approximately normal. This is evident from visually inspecting the data (i.e., histograms for each individual item) and from skew and kurtosis statistics. Treating the data as normally distributed is warranted. Finally, the relationships between the survey items are linear or approximately linear. This is evident from visually inspecting scatter plots for each pair of variables and from interpreting bivariate correlations for each pair. The subsequent use of linear models is therefore appropriate.

\subsection{Exploratory Factor Analysis}


After we had conducted the descriptive analysis, the 22 items that remained after the pilot study were subjected to exploratory factor analysis with all of them being analyzed simultaneously. Three factor analysis models were fit to the data with three, four, and five factors. The three-factor model was our starting point for the exploratory analysis because three factors are implied by the prior qualitative phase. Estimating the three-factor model yielded an $\mathrm{R}^{2}$ of 39.23 percent with all but three items "loaded" on to one of the three factors (i.e., to achieve a factor loading greater than plus or minus .30). However, the three-factor model was complicated by a fourth eigenvalue greater than one and a first factor that dominated the solution. Four factors were warranted empirically in that they could have produced a model with a better interpretation. Thus, a four-factor model was fit to the 22 items.

The four-factor model achieved an overall $\mathrm{R}^{2}$ of 44.90 percent, which was a marked improvement in fit over the three-factor model. Moreover, because the four-factor model entailed a simple structure (i.e., each item "loading" on only one factor), it offered an excellent interpretation. We labeled the four factors: low-repetition patterning, path-breaking approach, resource sustainability, and change intent. The factors (subscales) comprised three, three, nine, and five items. Example items, one from each subscale in the order (see Table 2) are "The majority of tasks undertaken in our firm cannot be captured in manuals"; "We move first in our market"; "Our current resource base supports our long-term competitiveness"; and "Our competitiveness depends on constant change to our processes and resources." Note that, while all 22 items were retained for the purposes of estimating the four-factor model, the same three items as before failed to load on to any factor.

For completeness, a five-factor model was fit to the 22 items. This model achieved an overall $\mathrm{R}^{2}$ of 49.69 percent. Although this represents an improvement over the three- and four-factor models, the improvement is only marginal considering the many additional parameters of the fivefactor model. Again, while all 22 items were modeled, the same three as before failed to load on to any of the five factors. Moreover, the five-factor model did not yield as theoretically pleasingly an 
interpretation as the four-factor model. In summary, because the four-factor model had the advantage of groupings of items with a meaningful interpretation, it better fit the data than competing specifications. We therefore proceed with the four-factor structure.

\subsection{Confirmatory Factor Analysis}

The exploratory factor analysis was useful for identifying the underlying structure of the data and was particularly warranted because the study was exploratory (i.e., the purpose is to develop measures). However, the exploratory factor analysis did not permit a test of unidimensionality. The problem is that each of the subscales of the DLCs scale should have been unidimensional because of the necessity of assigning meaning to subscales (Anderson \& Gerbing, 1988; Gerbing \& Anderson 1988). This had been our purpose for this first stage of the confirmation factor analysis (CFA). Unidimensionality can be easily tested within a restrictive or CFA framework. Thus, the CFA could have improved the exploratory factor analysis conducted earlier. Specifically, the CFA was conducted in two stages with the first having each subscale analyzed separately with unidimensionality being assessed independently. Furthermore, the separate subscale analyses provided information that was useful for assessing item validity and reliability. In the second stage, the subscales were analyzed jointly with a multi-factor CFA model. This permitted the convergent and divergent validity of the subscales to be assessed. The subscales should have converged on the same underlying factor (i.e., being highly correlated), but should have been different constructs (i.e., not perfectly correlated).

Note our approach to measurement is consistent with the notion of domain sampling (i.e., we follow the domain sampling paradigm). Thus, the specification of our measurement models is consistent with a classic reflective structure and not a formative one. Using the language of traditional psychometrics, our items are intended to be effect indicators and not cause indicators (Bollen 1989). The implied 'causal' direction is from the latent to the observed (and not from the observed to the latent). Our literature search and qualitative interviews established the domain of content for each of our subscales. Our items reflect these respective domains. They sample these domains and are thus not a definitive statement of the universe of all possible items. Our 
expectations in relation to these items are twofold. We anticipate (1) high inter-item correlations and (2) some uniqueness to each item. In summary, a reflective measurement structure is appropriate given these expectations and the general domain sampling approach.

On the basis of the exploratory factor analysis, 19 items were carried forward to the first stage of the CFA analysis. We expected that they would validly and reliably measure the four subscales and/or factors retrieved from the exploratory factor analysis. The model specification(s) for the tests of unidimensionality was straightforward. In each of the subsequent models, the observed variables were specified to be a function of a single latent variable plus measurement error. These models and all subsequent structural equations models were estimated using maximum likelihood with sample covariances as input; their model fits are reported in Table 3.

Insert Table 3 here

Low-repetition patterning was the first of the four subscales examined. This subscale had three items in total, specifically: "The majority of tasks undertaken in our firm cannot be captured in manuals", "The most important knowledge in our firm cannot be written down", and "There are few standard practices for new staff to follow when they join our firm." Fitting this three-item model to the sample data yielded a chi-squared of 3.22 (d.f. $=1, p=.07$ ). Thus, the model fits the data and hence the hypothesis that the items are unidimensional cannot be rejected. Without loss of generality, a constraint was imposed on two of the three regression coefficients to achieve identification. All the effects of the latent variable on the observed variables achieved significance ( $p$ $<.05)$. Thus, convergent validity was achieved. The standardized regression weights were in the range of .30 to .65 . Squaring the standardized regression weights yielded measures of item reliability, which was in the range of .10 to .40 . Strictly speaking, the items had more measurement error than explained variance. However, because the primary consideration was validity, all three items were retained. Moreover, the items were unidimensional and gave a good interpretation (i.e., meaning could be assigned to the subscale). 
The three items posited as measures of the path-breaking approach subscale were modeled next. The specific items were "We move first in our market", "Our resources are different from those of our competitors", and "We do not follow our competitors when making decisions about resource acquisitions." Fitting the three-item model to the data produces a chi-squared of .00 (d.f. $=1, p=$ .97). The model fitted the data and the hypothesis of unidimensionality could not be rejected. Again, without loss of generality, a simple equality constraint was imposed on two the three regression coefficients to achieve identification. The regression weights of all were significant $(p<.05)$ and thus, convergent validity was achieved. The regression weights were in the range of .48 to .57 . Squaring these values gives item reliabilities in the range of .23 to .33 . Note that, while there was more measurement error than explained variance in the items, they offered valid and unidimensional measurement.

Five items were posited as measures of change intent, specifically: "Our competitiveness depends on constant change to our processes and resources", "We change the rules of competition in our market", "Activities to be successful in our market are always changing", "We are always changing our practices in our firm", and "Our most important activities are those that create future opportunities." Fitting the five items to the sample data yielded a chi-squared of 9.23 with five degrees of freedom and a $p$-value of .08 . The model fits the data and thus the items were unidimensional. The five regression weights were significant $(p<.05)$ and the standardized regression coefficients fell in the range of .42 to .65 . Even though the items' reliability therefore fell in the range of .18 to .42 and had more measurement error than explained variance, the items were both valid measures of change intent and unidimensional.

The final subscale, resource sustainability, has nine items. However, an initial CFA model and several subsequent models failed tests of unidimensionality (i.e., single factor models did not fit the data). Using an iterative process, we established a subscale consisting of four items and found it to be unidimensional. The specific items of this refined subscale are "Our current resource base supports our long-term competitiveness", "Our staff is constantly seeking to improve their 
practices", "Our activities are focused on our strategic resources", and "We have practices focused on sustainable competitiveness." A single factor model with these four items modeled as observed variables fit the sample data $\left(\chi^{2}=2.18\right.$, d.f. $\left.=2, p=.34\right)$. Thus, unidimensional measurement was achieved. Because the four regression coefficients were significant at the $p<.05$ level, the four items offered valid measurement of resource sustainability. The standardized coefficients fell in the range of .51 to .76 and the corresponding item reliabilities fell in the range of .26 to .58 . Specifically, two of the items had more explained variance than measurement error. In summary, the four items offered valid and unidimensional measurement and item reliability is mixed. At this stage, 15 of the 19 items that were carried forward remained. Table 4 reports means and standard deviations and bivariate correlations for the items of the final DLCs scale.

Insert Table 4 here

\subsection{Convergent and divergent validity}

The second stage of the CFA analyses focuses on tests of convergent and divergent validity. This stage is warranted given the first-stage results: items for each of the four subscales are valid measures of their posited constructs and each of the four subscales is unidimensional. The model specification for the second stage was a classic multi-factor model. It was specified with reference to four factors and/or latent variables corresponding to the four dimensions of the proposed DLCS scale. The latent variables were correlated. Furthermore, each of the 15 items retained from the first stage of CFA analysis was modeled as an indicator of its posited construct. That is, restrictions were placed on the estimation of regression coefficients for the effects of the four latent variables on the 15 observed variables. Thus, each observed variable was found to be a function of a latent variable plus uniqueness (i.e., measurement error).

Estimating the multi-factor model yielded a chi-squared of 217.79 (d.f. $=84, p<.05$ ) showing that the multi-factor model did not achieve an exact fit to the sample data. Tests of exact fit imply a strict hypothesis: the "cross-loadings" are zero in the population (i.e., the restrictions placed on the 
estimation of regression coefficients for effects of latent variables on observed variables). Although satisfying this strict hypothesis is not a realistic expectation for an item-development study, the result of this test should be noted as verifying our process. Other measures of model fit support a different interpretation; that is, the model has good fit to the sample data, but does not fit exactly (Jöreskog \& Sörbom, 1996). For example, the normed chi-squared $\left(\chi^{2} /\right.$ d.f.) is 2.53 and the root mean square error of approximation (RMSEA) is .05. These results indicate that the average residual is small given the parameterization of the model and the sample size. The Tucker-Lewis index (TLI) and the comparative fit index (CFI) have values of .90 and .92, respectively. Both indicate acceptable fit. As well, the traditional goodness-of-fit indices (GFIs) and AGFI (adjusted goodness-of-fit index) are .95 and .93 , respectively (Bollen, 1989). Because these also indicate good fit, the model parameters warrant interpretation.

In total, the multi-factor model has 38 parameters, which Table 5 reports: estimates of the correlations among the latent variables of which there are six in total. Table 5 also shows that there are 16 each of estimates of regression coefficients and variances of the error terms. The correlations fell in the range of .24 to .73 with all achieving significance at the $p<.05$ level. Thus, convergent validity is achieved for the four subscales of the proposed DLCs scale. The regression coefficients are significant at $p<.05$ level. This provides further evidence of convergent validity at the item level. The standardized coefficients range from .31 to .72 . Because the squared regression coefficients fell in the range of .10 to .52 , it showed that some of the items were subject to a considerable amount of measurement error. However, the items were valid measures because the regression coefficients achieved significance (i.e., each individual item converged on its posited construct).

Insert Table 5 here

Divergent validity is satisfied if the subscales are not the same constructs (Jöreskog \& Sörbom, 1996). This can be tested by fixing the correlation between two subscales to unity (i.e., one) and reestimating the model. Comparing the fit of the fixed model(s) to the free model (i.e., the original 
multi-factor model) provides a test(s) of divergent validity. Specifically, the hypothesis that the subscales are the same constructs is rejected if the free model has better fit to the sample data than the fixed model(s). In our research, six comparisons were performed because there were six correlations. In each case, the free model achieved better fit to the sample data than did the fixed model(s). Thus, divergent validity was achieved for the four subscales of the proposed DLCs scale. In summary, the four subscales achieved convergent and divergent validity (i.e., they were separate but related dimensions of an underlying construct). As well, the items were valid but varied in reliability (i.e., for some items, the proportion of variance attributed to measurement error was nontrivial).

Common methods bias offers one potential explanation for the observed correlations among the items of the DLC subscales (Podsakoff, MacKenzie, Lee, \& Podsakoff, 2003). To test this possibility we respecified the multi-factor model incorporating a common method factor. The specification is as follows. Each item is specified as a function of its posited construct, a uniqueness (measurement error) and a factor common to all of the observed variables. Thus, each item is subject to three sources of influence (i.e., a substantive factor, a method factor, and an error term). Estimating the common method factor model produced a chi-square value of 138.94 (d.f. $=69, p<$ .05). This represents a significant improvement in fit over the original multi-factor model $\left(\chi^{2} \Delta=\right.$ 78.85 , d.f. $=15, p<.05)$. Thus, a method factor is evident. However, the impact of the method factor is minimal. Approximately half of the estimated effects of the method factor (regression coefficients for the effects of the method factor on the measured variables) are not significant. Moreover, none of the effects of the substantive (theoretical) factors of interest on the measured variables are attenuated to the point of non-significance. In summary, a method factor is evident but its impact on the measured variables is minimal. Given these empirical results, we proceed without a method factor.

Convergent validity can be further explored at the level of each of the dimensions of the multi-factor model; however, this test requires re-specifying the multi-factor model as a higher- 
order factor model. Testing such a model has the immediate advantage of providing an initial test of the convergent validity of each of the dimensions (subscales) of the DLC construct. The specification of the higher-order factor model is as follows. The "lower-order" factor structure is per the multifactor model (i.e., each item of each subscale is specified as a function of its posited latent variable plus a uniqueness term). The defining characteristic of the model is its specification of a fifth latent variable. The four latent variables representing the four subscales of the DLC construct are regressed on this latent variable. Essentially, the "higher-order" structure replaces the six factor intercorrelations with four regression coefficients. Thus, the model has two fewer parameters than the multi-factor model. The latent variable of higher order thus represents an overall DLC construct. Estimating the higher-order factor model yields a chi-squared value of 220.49 (d.f. $=86, p<$ .05). Strictly speaking, the higher-order and multi-factor models are not nested models so that a comparison of chi-squared values is not appropriate. Note, though that the chi-squared values for the models are essentially the same. The additional useful outputs of the higher-order factor model are the regression coefficients for the effects of the higher-order factor on the four lower-order factors (the effects on the subscales representing the dimensions of the DLC construct). These regression coefficients can be interpreted as measures of the validity of the dimensions (as the regression coefficients for the effects of the first-order factors on their measured variables are measures of item validity). Because all four of the estimated regression coefficients achieve significance $(p<.05)$, all four subscales are valid dimensions of the DLC construct. Note that the regression coefficients for the path-breaking, resource sustainability, and change intent dimensions fall in the range of .72 to .84 , whereas the regression coefficient for the low repetition patterning dimension is .49. Constraining the coefficients to be equal and re-estimating the model produces a poorer fit $\left(\chi^{2}=277.73\right.$, d.f. $=89, p<.05 ; \chi^{2} \Delta=57.23$, d.f. $\left.=3, p<.05\right)$. Thus, the dimensions do not appear to be equally important to the measurement and representation of the DLC construct.

In summary, the higher-order factor model is consistent with our thinking and theorizing in that a higher-order factor consistent with the DLC construct can be specified and tested. The higher- 
order construct explains a substantial proportion of the variation in the four dimensions (subscales). The R-squared values for these regressions are typically in the range of .50 (with the exception of low-repetition patterning). In turn, the first-order factors explain a substantial proportion of the variation in their measured variables (per the multi-factor model). Given this empirical support for our conceptualization of the DLC construct, a further and more specific test of the role of each dimension in explaining important organizational outcomes is warranted. Thus, we subsequently present tests of predictive validity incorporating a rival theoretical explanation for the observed variation in the outcome's variables of interest.

\subsection{Full Structural Equation Models}

The tests to this point establish the convergent and divergent validity of the four subscales of the proposed DLCs scale, plus the validity of the individual items of each subscale. This is a crucial prerequisite for a successful scale development exercise. Furthermore, the utility of the proposed DLCs scale is greatly advanced by tests of predictive validity. These tests are presented subsequently and are implemented by specifying and testing three full structural equation models. The term "full model" refers a latent variable structural equation model with observed and latent explanatory and dependent variables (Jöreskog \& Sörbom, 1996). In our opinion, establishing that the four subscales are associated with performance outcomes is not enough to warrant their entry into the literature. The subscales must add explanatory power beyond that offered by existing scales (e.g., the organizational learning subscales). The full structural equations models provide the modeling framework for this test and an initial test of the predictive validity of the proposed DLCs scale.

The latent dependent variables in the full structural equations models relate to financial and customer performance. The specific measures used are based on existing literature (e.g., Covin \& Slevin, 1989; Gupta \& Govindarajan, 1984). Twelve items in total were used, to which respondents answered on five-point rating scales (six items for each performance dimension). Example items for financial performance are: profit per employee and return on assets. For customer performance, example items include: increasing customer satisfaction and anticipating customer needs. Higher 
scores imply higher perceived performance. The latent explanatory variables in the full structural equations models are the four subscales of the proposed DLCs scale plus the two subscales of the organizational learning scale. These are the well-known exploitation and exploration subscales. These subscales have eight and four indictors respectively. To achieve unidimensional measurement we subject the original 20 items (10 items per subscale) to the same process of testing and revision as per the one-factor models described earlier.

Briefly, the three full structural equations models reported follow essentially the same specification. Each of the eight latent variables is measured only by its posited indictors. The two latent variables representing firm performance are regressed on the six latent variables. They correspond to the four subscales of the proposed DLCs scale and the two latent variables representing the exploitation and exploration subscales. As discussed subsequently, the three models differ in important ways, specifically, in how the possible correlations among the subscales are represented. Accounting for these correlations is important because they represent important sources of shared influence. The most parsimonious specification sets the correlations to zero; subsequent specifications introduce correlations.

Consider the first of the three full structural equations models (Model 1). We described above the specification that two latent dependent variables regressed on six latent explanatory variables. In total, 12 regression coefficients are estimated in the structural sub-model. No correlations among the explanatory latent variables or among the dependent latent variables are specified. In the structural sub-model, only the regression coefficients for the effects of the six subscales on the performance constructs were estimated (i.e., the factor-on-factor regressions), as was the variance of prediction errors for the latent dependent variables. The measurement sub-model has a simple structure, that is, items are related only to their posited constructs. Thus, the specification of Model 1 is essentially a multivariate regression model controlling for measurement error. In this way, Model 1 is consistent with the specification of the typical regression model and provides a baseline for comparison with Models 2 and 3. Estimating Model 1 yields a chi-squared of 2,957.91 (d.f. = 690, 
$p<.05)$ meaning that the fit is not exact. Other fit measures indicate poor to adequate model fit to the sample data $\left(\chi^{2} /\right.$ d.f. $=4.29, \mathrm{RMSEA}=.07, \mathrm{TLI}=.72, \mathrm{CFI}=.74, \mathrm{GFI}=.77$, and AGFI $\left.=.74\right)$. Table 6 reports the estimates, but their interpretation is not considered here explicitly. We next consider the specification of Model 2.

This specification relaxes the assumptions that the latent explanatory variables are independent and that the dependent variables are independent. However, a defining characteristic of the specification of Model 2 is that the correlations among the subscales of the organizational learning and DLCs scales are not estimated. Thus, Model 2 provides initial insight into the unique contribution of the established and proposed scales relating to the performance outcomes studies. Specifically, the two subscales of the organizational learning scale, the four subscales of the proposed DLCs scale, and the two performance variables are all correlated. Briefly, these correlations are warranted on theoretical grounds with the literature establishing the correlation between the organizational learning subscales (Alexiev et al., 2010; Li et al., 2010; Tamayo-Torres et al., 2011). For example, the tests of convergent validity establish non-zero correlations among the four subscales of the proposed DLCs scale. With financial and customer performance both being performance constructs, a correlation is warranted. More generally, Model 2 provides a stronger test than does Model 1 of the links between the inputs and outputs studied. Because correlations among the explanatory variables allow for shared influences, the specification of Model 2 better represents possible shared influences within subscales.

Estimating Model 2 yields a chi-squared of 2,292.00 (d.f. $=682, p<.05$ ) thus representing a significant improvement in fit vis-⿳亠丷⿵冂- vis Model $1\left(\Delta \chi^{2}=665.91\right.$, d.f. $\left.=8, p<.05\right)$. Other fit measures show improvement over Model $1\left(\chi^{2} /\right.$ d.f. $=3.361, \mathrm{RMSEA}=.06, \mathrm{TLI}=.80, \mathrm{CFI}=.81, \mathrm{GFI}=.84$, and $A G F I=.82$ ). Specifying the correlations within each of the subscales yields a better fitting model (i.e., the fit is improved because the latent structure is better represented). Table 6 reports the regression coefficients for the effects of the latent explanatory variables on the latent dependent variables. The 
robustness of the regression coefficients to the shared influences implied by the correlations remains in question.

Insert Table 6 here

Lastly, Model 3 is the final full structural equation model that adds correlations among the organizational learning and DLCs subscales. The proposed DLCs scale is intended to complement the organizational learning constructs. Thus, the specification of Model 3 includes correlations among the complete set of antecedents. Estimating Model 3 yields a chi-squared of 1,673.49 with 674 degrees of freedom, which implies that $p<.05$. The fit is significantly improved compared to Model $2\left(\Delta \chi^{2}=618.51\right.$, d.f. $\left.=8, p<.05\right)$ and other fit measures are further improved $\left(\chi^{2} /\right.$ d.f. $=2.48$, RMSEA $=$ $.05, \mathrm{TLI}=.87, \mathrm{CFI}=.88, \mathrm{GFI}=.87$, and $\mathrm{AGFI}=.85)$. While the descriptive fit indices are still marginal, the normed chi-squared and RMSEA indicate good model fit to the sample data. Thus, something like the specification of Model 3 plausibly represents the data. To be sure, Model 3 has improved fit compared to the specifications of Models 1 and 2. While they may have the advantage of greater parsimony, Model 3 provides the strongest possible test of the factor-on-factor regressions.

Table 6 reports the regression coefficients, which warrant consideration especially given the comparative improvement in fit of Model 3. Specifically, three of the eight regression coefficients achieve significance at the $p<.05$ level: resource sustainability $\rightarrow$ financial performance $(b=.71, t=$ 2.61), low-repetition patterning $\rightarrow$ customer performance $(\theta=.18, t=2.86)$, and resource sustainability $\rightarrow$ customer performance $(B=.79, t=3.09)$. This pattern of results highlights the crucial importance of resource sustainability. Indeed, this importance is a "core" finding of this paper. These effects are robust to all three specifications of the full structural equations models. While support for the effect of low-repetition patterning on customer performance is consistent, support for its effect on financial performance is not. Thus, the subscales offer different pathways to the performance outcomes. Furthermore, note that the effect of change intent on financial performance is negative and marginally significant $(b=-.29, t=-1.66)$. The negative sign warrants 
further theorizing. The most striking null results, however, are the non-significant results for the effects of the organizational learning subscales on the performance outcomes. This pattern of results warrants much further discussion. Note that the $\mathrm{R}^{2}$ values for the regressions are 20 percent and 23 percent, respectively, for the latent variables representing financial and customer performance.

\section{Discussion and conclusions}

Progress in the dynamic capabilities field beyond the conceptual has been dominated by studies focusing on the observable and measurable. The problem with such dominance is that it is well recognized in conceptual papers that the higher-level (Teece, 2007) or higher-order (Eisenhardt \& Martin, 2000) capabilities drive strategy. If we cannot or do not seek to measure the higher-order capabilities, then we are not able to guide executive leaders in fulfilling their roles optimally. Our central contribution is in providing a dedicated measurement scale for those higher- or second-order dynamic capabilities that have been most difficult to demystify: Dynamic Learning Capabilities (DLCs). As such, this discussion focuses exclusively on DLCs, and their relationship with performance. To achieve this we incorporate the accepted scale on the focus on learning, as well as additional aspects of theorized contributors, such as low-repetition patterning, the use of specialized resources to sustainable competitiveness, and organizational intent to compete through change (Eisenhardt \& Martin, 2000; Helfat, Finkelstein, Mitchell, Peteraf, Singh, Teece, \& Winter, 2007). It is these latter aspects that existing scales are yet to fully contend with, causing the content validity issues that we addressed in this paper. These theories take capabilities beyond static (Wernerfelt, 1984) scales, and beyond the explication of dynamic functional capabilities.

With its focus on higher-order DLCs, our paper develops and validates a measurement instrument to operationalize and measure this construct. This may be useful to firms that want to design their systemic processes by directing resources and learning to advance lower-order capability development. As such, we followed a rigorous development and validation process, using five-steps and four sources of data to present a parsimonious six dimensional scale of DLCs. Our results indicate that we can establish these additional dimensions empirically and that they 
complement the existing learning scales (Jansen et al., 2006) by converging on a higher-order factor model. The resulting scale enables us to explore the relationships between our sub-constructs and forms of performance to point to the type of work for which this scale provides a foundation. Overall, it helped us to address Felin and Foss's (2011) concerns about the number of experiences dominating the empiricization of the routines and capabilities field, by distinguishing between high and low levels of routines and capabilities, thereby shifting the emphasis from frequency to quality.

\subsection{Implications for theory}

The first and foremost contribution of this paper is the development of four subscales which, together with the two existing learning scales, can measure the presence and nature of DLCs in firms. The first subscale, resource sustainability, consists of items intended for the original "predominant resources" and "competitive intent" factors. In accordance with this approach, because all the items in this subscale were focused on how firms use their resource base to sustain and improve competitiveness, we renamed it "resource sustainability" to align it with the items. Theoretically, this new factor made sense because the items point toward building a forwardfocused, sophisticated resource base as a platform for innovation and growth. The next two factors, namely, low repetition patterning and change intent, operated as intended. The last subscale, "pathbreaking", was new and drew on three items that all indicated independent action in leading the market. It extends existing frameworks (Ambrosini and Bowman, 2009; Hine, et al. (2014); Schilke, 2014) and fits well with the arguments earlier in this paper that DLCs are by definition changefocused, which inevitably produces innovative leadership. Therefore, this dimension was initially retained as part of the overall construct of DLCs, but dropped after further testing as explained in the next section.

The second contribution is visible in how these subscales relate to performance. To understand this we used the four factors and the existing learning subscales, exploration and exploitation, to develop three full structural models to test the predictive validity of our subscales (see Table 6) with financial and customer performance as dependent variables. Simple correlations 
showed that all these scales are related to the performance outcomes. However, once these relationships were estimated as structural equation models (SEMs), a more subtle pattern of influence emerged, which provides important direction to further theorizing and indeed further research on learning capabilities.

A particularly useful exercise is to assess the robustness of the effects of the latent explanatory variables on the latent dependent variables through the competing specifications of Models 1 to 3 . We consider the impacts on financial performance first. Under the specification of Model 1, low repetition patterning and resource sustainability matter for performance but, in the latter more accurate models, it is resource sustainability and change intent that are most important for financial performance. Resource sustainability relates to the long-term sustainability of the firm, which explains its importance to performance (Sambharya \& Lee, 2014). However, change intent negatively relates to performance. As we remember that all the sub-constructs were positively related to financial performance in the simple correlations, and that competitive intent was consistently negative across all three models, we are led to hypothesize that there is a cost to change. This concept of cost to change links well with our earlier arguments that dynamic capabilities, and especially dynamic learning capabilities, take time to benefit the firm, and can only be fully understood through longitudinal research (see next section). Change does not always lead to improved performance but, if it does, there is likely to be a substantial lag between change and its effect.

When considering the role of the subscales in customer performance, we see the consistent positive effect of low repetition patterning across all three models. Early marketing literature has argued for consistency and therefore high repetition in how firms deliver service and therefore value to their customers (e.g. Parasuraman, Zeithaml \& Berry, 1985). Yet, consistent with newer developments (e.g. Sheth, Sisodia, \& Sharma, 2000), our results indicate that firms must understand the individual needs of customers and use DLCs to address these needs in a market environment that is far more diverse, changeable and uncertain than ever before. While local adaptation thus 
leads to satisfied customers, the necessity to anticipate customer needs is never ending. In addition, resource sustainability again best explains the variance in customer performance (Hunt \& Morgan, 1995). The importance of using an appropriate resource base to sustain performance therefore provides the platform for growth as it is those resources that support long-term performance such as sophisticated and specialized human and physical capital. Such capital bears the hallmarks of being valuable, rare, imperfectly inimitable and imperfectly substitutable: VRIN (Barney, 1991).

However, not all sub-constructs are consistently important, most notably, the path-breaking construct that emerged from our analysis. Results from the higher-order models indicated that this factor was valid, but not reliable. Where the three other factors exhibited similar results, pathbreaking did not. Indeed, the structural models showed that its predictive validity was also mixed. While moving early and thereby distinguishing the firm from its competitors is intuitively important in firms with high levels of DLCs, perhaps the long-term nature of this construct means that it will take time for its effect to become visible. In fact, theoretically, this construct could be antecedent to DLCs, rather than an aspect of the construct itself.

\subsection{Future research}

While the discussion above already indicates a number of interesting approaches to take with our new scales, there are also some avenues that we have not explored in this paper. More recently, there has been a move towards measuring the relationships between different levels of capabilities and performance, for example, DFCs and OCs with performance (Karna, 2015) and DLCs and DFCs with performance (Schilke, 2014). Schilke (2014) provides an approach to measuring DLCs, by narrowing his focus to alliances. However, his paper does illustrate one of the issues that we address, namely that all measurement to date has focused on functional areas or strategic types, such as the alliances in his focus. It remains that the higher-order DLCs that are more broadly important to develop different types of functional capabilities are not covered even in recent publications, a gap that our measurement scale will help to address. 
The modelling in this paper has focused on direct and linear effects. However, organizations are themselves complex systems, and other effects may be possible and can be considered in future research. To illustrate, the structural models showed that low-repetition patterning is somewhat different to the other three dimensions. This is important, because we can theoretically posit that such patterning may need to be present for the other dimensions to be successful. Zollo and Winter (2002, p. 344) stress the impact of learning mechanisms, especially constant knowledge articulation and the process of codification (rather than simply the codification itself) on the process of R\&D, restructuring, re-engineering and post-acquisition integration that leads to the evolution of operating routines. This points to the low repetition patterning factor's moderating potential.

In a similar vein, the other explanatory variables may require resource sustainability to be a prerequisite, which may point to mediatory relationships. Other non-linearities are also possible, an example being the effect of resource sustainability on performance, linear or curvilinear. Although a linear functional form provides a good result, there may be decreasing returns to resource inputs, which should be the focus of future projects that use these subscales. Our final suggestion is that, at an empirical level, the relationships between the DLC dimensions and other strategy variables could be different in different contexts. This is something that should be empirically investigated in subsequent studies.

An important limitation of our research is the cross-sectional nature of our data. Several tenets of our findings explored above pointed to questions that can only be answered through a longitudinal design. For example, some of the sub-constructs, such as change intent and exploration, showed negative relationships because it takes time for these practices to positively affect financial performance. The literature supports such an assertion (e.g., Kim, Song, \& Nerkar, 2012). It is our intention that this scale with its subscales should be tested and used in longitudinal research designs where independent and dependent variables can be tested at different time points. Such research could be further extended to create mediatory models, where dynamic functional capabilities such as internationalization or innovation can mediate the relationships between DLCs and performance. 
We argued previously that dynamic capability theory has been adopted quickly, and that, especially for DLCs, the transition from conceptual to empirical has been limited. This widespread attention has spilled over to the world of the practitioner. Yet, as the lack of measurement scales for DLCs has negated proper testing and development, it is possible that adopting and using our devised scale may create more problems than solutions. The intention is that this scale will promote further empirical study into both DLCs and the relationship between different approaches to DLCs and firm performance. Although such study will further advance the theory of dynamic capabilities, we caution researchers to take care not to combine all the items into one measure of DLCs. Such an action would not fit dynamic capability theory and thus diminish our quest to provide both a more taxonomical and a more functional evidential approach to the study of dynamic capabilities. An amorphous listing of items would seem a backward step.

To conclude, we suggest that, for practitioners, this tool can be used to estimate the level of high-level capability development in a firm. This provides an effective capability auditing tool with a clear set of assessable parameters that managers can monitor over time and use to respond to deficiencies and changing competitive circumstance in a rapid discretionary fashion. 


\section{References}

Alexiev, A. S., Jansen, J. J. P., Van den Bosch, F. A. J., \& Volberda, H. W. (2010). Top management team advice seeking and exploratory innovation: The moderating role of TMT heterogeneity. Journal of Management Studies, 47, 1343-1364

Ambrosini, V., \& Bowman, C. (2009). What are dynamic capabilities and are they a useful construct in strategic management? International Journal of Management Reviews, 11(1), 29-49.

Ambrosini, V., Bowman, C. \& Collier, N. (2009). Dynamic capabilities: An exploration of how firms renew their resource base. British Journal of Management, 20, S9-S24.

Anderson, J. C., \& Gerbing, D. W. (1988). Structural equation modeling in practice: A review and recommended two-step approach. Psychological Bulletin, 103, 411-423.

Arend, R. J., \& Bromiley, P. (2009). Assessing the dynamic capabilities view: spare change, everyone? Strategic Organization, 7, 75-90.

Bagozzi, R. P., Yi, Y., \& Phillips, W. (1991). Assessing construct validity in organizational research. Administrative Science Quarterly, 36, 421-458.

Barreto, I. (2010). Dynamic capabilities: A review of past research and an agenda for the future. Journal of management, 36(1), 256-280.

Becker, M. C. (2004). Organizational routines: a review of the literature. Industrial and Corporate Change, 13(4), 643-678.

Bollen, K. A. (1989). Structural equations with latent variables, Wiley \& Sons, New York, NY, 1989.

Byrne, B. M.: 2001, Structural equation modeling with AMOS: Basic concepts, applications and programming. New Jersey: Lawrence Erlbaum.

Camison, C., \& Fores, B. (2010). Knowledge absorptive capacity: New insights for its conceptualization and measurement. Journal of Business Research, 63, 707-715.

Cardon, M. S., Gregoire, D. A. Stevens, C. E., \& Patel, P. C. (2013). Measuring entrepreneurial passion: Conceptual foundations and scale validation. Journal of Business Venturing, 28, 373-396. 
Cepeda, G., \& Vera, D. (2007). Dynamic capabilities and operational capabilities: A knowledge management perspective. Journal of Business Research, 60, 426-437.

Collis, D. J. (1994). How valuable are organizational capabilities? Strategic Management Journal, 15, $143-152$.

Covin, J. G., \& Slevin, D. P. (1989). Strategic management of small firms in hostile and benign environments. Strategic Management Journal, 10, 75-87.

Danneels, E. (2012). Second-order competences and Schumpeterian rents. Strategic Entrepreneurship Journal, 6: 42-58.

Danneels, E. (2008). Organizational antecedents of second-order competences. Strategic Management Journal, 29, 519-543

DeVellis, R. F. (2012). Scale development. Los Angeles, CA: Sage.

Di Stefano, G., Peteraf, M., \& Verona, G. (2014). The organizational drivetrain: A road to integration of dynamic capabilities research. The Academy of Management Perspectives, 28(4), 307-327.

Dixon, S. E., Meyer, K. E., \& Day, M. (2010). Stages of organizational transformation in transition economies: A dynamic capabilities approach. Journal of Management Studies, 47, 416-436.

Drnevich, P. L., \& Kriauciunas, A. P. (2011). Clarifying the conditions and limits of the contributions of ordinary and dynamic capabilities to relative firm performance. Strategic Management Journal, $32(3), 254-279$.

Eisenhardt, K. M. (1989). Building theories from case study research. Academy of Management Review, 14, 532-550.

Eisenhardt, K. M., \& Graebner, M. E. (2007). Theory building from cases: Opportunities and challenges. Academy of Management Journal, 50(1): 25-32.

Eisenhardt, K. M., \& Martin, J. A. (2000). Dynamic capabilities: What are they? Strategic Management Journal, 21, 1105-1121. 
Ellonen, H. K., Jantunen, A., \& Kuivalainen, O. (2011). The role of dynamic capabilities in developing innovation-related capabilities. International Journal of Innovation Management, 15(03), 459478.

Felin, T., \& Foss, N. J. (2011). The endogenous origins of experience, routines, and organizational capabilities: the poverty of stimulus. Journal of Institutional Economics, 7(2), 231-256.

Flatten, T. C., Engelen, A., Zahra, S. A., \& Brettel, M. (2011). A measure of absorptive capacity: Scale development and validation. European Management Journal, 29, 98-116.

Gerbing, D. W., \& Anderson, J. C. (1988). An updated paradigm for scale development incorporating unidimensionality and its assessment. Journal of Marketing Research, 25, 186-192.

Glaser, B. G., \& Strauss, A. L. (2009). The discovery of grounded theory: Strategies for qualitative research. New Jersey: Transaction Publishers.

Grant, R. M. (1996). Toward a knowledge-based theory of the firm. Strategic Management Journal, $17,109-122$.

Gray, C. (2004). Management development in European small and medium enterprises. Advances in Developing Human Resources, 6, 451-469.

Gupta, A. K., \& V. Govindarajan (1984). Business unit strategy, managerial characteristics, and business unit effectiveness at strategy implementation. Academy of Management Journal, 27, 25-41.

Gwinner, K. P., Gremler, D. D., \& Bitner, M. J. (1998). Relational benefits in services industries: The customer's perspective. Journal of the Academy of Marketing Science, 26, 101-114.

Hamel. G. \& Prahalad, C. K. (1989). Strategic intent. Harvard Business Review. 89(3), 63-76.

He, Z. L., \& Wong, P. K. (2004). Exploration vs. exploitation: An empirical test of the ambidexterity hypothesis. Organization Science, 15(4), 481-494.

Helfat, C. E., Finkelstein, S., Mitchell, W., Peteraf, M. A., Singh, H., Teece, D. J., \& Winter, S. G. (2007). Dynamic capabilities: Understanding strategic change in organizations. London: Blackwell.

Helfat, C. E., \& Peteraf, M. A. (2003). The dynamic resource-based view: Capability lifecycles. Strategic Management Journal, 24, 997-1010. 
Hine, D., Parker, R., Pregelj, L., \& Verreynne, M. (2014). Deconstructing and reconstructing the capability hierarchy. Industrial and Corporate Change. 23(5): 1299-1325.

Hogan, S. J., Soutar, G. N., McColl-Kennedy, J. R., \& Sweeney, J. C. (2011). Reconceptualizing professional service firm innovation capability: Scale development. Industrial Marketing Management, 40, 1264-1273

Hunt, S. D., \& Morgan, R. M. (1995). The comparative advantage theory of competition. The Journal of Marketing, 59(April), 1-15.

Jansen, J. J. P., Van den Bosch, F. A. J., \& Volberda, H. W. (2006). Exploratory innovation, exploitative innovation, and performance: Effects of organizational antecedents and environmental moderators. Management Science, 52, 1661-1674.

Jansen, J. J. P., Vera, D., \& Crossan, M. (2009). Strategic leadership for exploration and exploitation: The moderating role of environmental dynamism. The Leadership Quarterly, 20, 5-18.

Jöreskog, K. G., \& Sörbom, D. (1996). LISREL 8 user's reference guide. Uppsala, Sweden: Scientific Software International.

Kale, P., \& Singh, H. (2007). Building firm capabilities through learning: the role of the alliance learning process in alliance capability and firm-level alliance success. Strategic Management Journal, 28, $981-1000$.

Karna, A., Richter, A., \& Riesenkampff, E. (2015). Revisiting the role of the environment in the capabilities-financial performance relationship: A meta-analysis. Strategic Management Journal. DOI: 10.1002/smj.2379.

Kim, C., Song, J., \& Nerkar, A. (2012). Learning and innovation: Exploitation and exploration trade-offs. Journal of Business Research, 65(8), 1189-1194.

Kleinschmidt, E. J., De Brentani, U., \& Salomo, S. (2007). Performance of global new product development programs: A resource-based view. Journal of Product Innovation Management, 24(5), 419-441. 
Lavie, D., Stettner, U., \& Tushman, M. L. (2010). Exploration and exploitation within and across organizations. The Academy of Management Annals, 4(1), 109-155.

Lebas, M., \& Euske, K. (2002). A conceptual and operational delineation of performance. In A. Neely (Ed.), Business performance measurement: Theory and practice (pp. 65-79). Cambridge: Cambridge University Press.

Li, W., Veliyath, R., \& Tan, J. (2013). Network characteristics and firm performance: An examination of the relationships in the context of a cluster. Journal of Small Business Management, 51, 1-22.

Li, Y., Zhou, N., \& Si, Y. (2010). 'Exploratory innovation, exploitative innovation, and performance: Influence of business strategies and environment'. Nankai Business Review International, 1, 297-316

Lyon, D. W., Lumpkin, G. T., \& Dess, G. G. (2000). Enhancing entrepreneurial orientation research: Operationalizing and measuring a key strategic decision making process. Journal of Management, 26, 1055-1085.

Macher, J. T., \& Mowery, D. C. (2009). Measuring dynamic capabilities: practices and performance in semiconductor manufacturing. British Journal of Management, 20, S41-S62.

Makadok, R. (2001). Toward a synthesis of the resource-based and dynamic-capability views of rent. Strategic Management Journal, 22, 387-401.

Malhotra, N. K., Hall, J., Shaw, M., \& Oppenheim, P. (2002). Marketing research: An applied orientation (2nd ed.). Frenchs Forest: Prentice Hall.

March, J. G. (1991). Exploration and exploitation in organizational learning. Organization Science, 2(1), $71-87$.

Marcus, A. A., \& Anderson, M. H. (2006). A general dynamic capability: Does it propagate business and social competencies in the retail food industry? Journal of Management Studies, 43, 19-46.

Miles, M. B., \& Huberman, A. M. (1994). Qualitative data analysis: An expanded sourcebook. Beverly Hills, CA: Sage. 
Mort, S.G., Weerawardena, J., \& Liesch, P. (2012). Advancing entrepreneurial marketing: Evidence from born global firms. European Journal of Marketing, 46(3/4), 542-561.

Nelson, R. R., \& Winter, S. (1982). An evolutionary theory of economic change. Cambridge, MA: Belknap Press.

Nunnally, J. C. (1978). Psychometric theory. New York: McGraw-Hill.

Oh, L-B., Teo, H-H., \& Sambamurthy, V. (2012). The effects of retail channel integration through the use of information technologies on firm performance. Journal of Operations Management, 30 , $368-381$.

O'Regan, N., \& Ghobadian, A. (2004). Testing the homogeneity of SMEs: The impact of size on managerial and organisational processes. European Business Review, 16, 64-79.

Parasuraman, A., Zeithaml, V. A., \& Berry, L. L. (1985). A conceptual model of service quality and its implications for future research. The Journal of Marketing, 49(Fall), 41-50.

Pavlou, P. A., \& El Sawy, O. A. (2011). Understanding the elusive black box of dynamic capabilities. Decision Sciences, 42, 239-273.

Peteraf, M., Di Stefano, G., \& Verona, G. (2013). The elephant in the room of dynamic capabilities: Bringing two diverging conversations together. Strategic Management Journal, 34(12), 13891410.

Podsakoff, P. M., MacKenzie, S. B., Lee, J-Y., \& Podsakoff, N. P. (2003). Common method biases in behavioral research: A critical review of the literature and recommended remedies. Journal of Applied Psychology, 88, 879-903.

Protogerou, A., Caloghirou, Y., \& Lioukas, S. (2012). Dynamic capabilities and their indirect impact on firm performance. Industrial and Corporate Change, 21(3), 615-647.

Putnam, L. (1983). The interpretive perspective: an alternative to functionism. In L. Putnam, \& Pacanowsky, M. (Eds.), Communication and organisations: An interpretive approach (pp. 3154). Newbury Park: Sage. 
Ren, C. R., \& Guo, C. (2011). Middle managers' strategic role in the corporate entrepreneurial process: Attention-based effects. Journal of Management, 37, 1586-1610.

Rothaermel, F. T., \& Hess, A. M. (2007). Building dynamic capabilities: Innovation driven by individual, firm-, and network-level effects. Organization Science, 18(6), 898-921.

Sambharya, R. B., \& Lee, J. (2014). Renewing Dynamic Capabilities Globally: An Empirical Study of the World's Largest MNCs. Management International Review, 54(2), 137-169.

Sandberg, J. (2001). The constructions of social constructionism. In S. E. Sjöstrand, J. Sandberg, \& M. Tyrstrup (Eds.), Invisible management: The social construction of leadership (pp. 28-48). London: Thomson Learning.

Schilke, O. (2014). Second-order dynamic capabilities: How do they matter? The Academy of Management Perspectives, 28(4), 368-380.

Schumpeter, J. A. (1934). The theory of economic development. Cambridge, MA: Harvard University Press.

Shepherd, D. A., \& DeTienne, D. R. (2005). Prior knowledge, potential financial reward, and opportunity identification. Entrepreneurship theory and practice, 29, 91-112.

Sheth, J. N., Sisodia, R. S., \& Sharma, A. (2000). The antecedents and consequences of customercentric marketing. Journal of the Academy of Marketing Science, 28(1), 55-66.

Stratman, J. K., \& Roth, A. V. (2002). Enterprise resource planning (ERP) competence constructs: Twostage multi-item scale development and validation. Decision Sciences, 33, 601-628.

Strauss, A., \& Corbin, J. (1990). Basics of qualitative research - Grounded theory, procedures and techniques. London: Sage.

Szulanski, G. (1996). Exploring internal stickiness: Impediments to the transfer of best practice within the firm. Strategic Management Journal, 17, 27-43.

Tamayo-Torres, J., Ruiz-Moreno, A., \& Llorens-Montes, J. (2011). The influence of manufacturing flexibility on the interplay between exploration and exploitation: The effects of organizational learning and the environment. International Journal of Production Research, 49, 6175-6198. 
Teece, D. J. (2007). Explicating dynamic capabilities: The nature and microfoundations of (sustainable) enterprise performance. Strategic Management Journal, 28, 1319-1350.

Teece, D. J. (2014). The foundations of enterprise performance: Dynamic and ordinary capabilities in an (economic) theory of firms. The Academy of Management Perspectives, 28(4), 328-352.

Teece, D. J., Pisano, G., \& Shuen, A. (1997). Dynamic capabilities and strategic management. Strategic Management Journal, 18(7), 509-533.

Vorhies, D. W., \& Morgan, N. A. (2005). Benchmarking marketing capabilities for sustainable competitive advantage. Journal of Marketing, 69(1), 80-94.

Wang, C. L., \& Ahmed, P. K. (2007). Dynamic capabilities: A review and research agenda. International Journal of Management Reviews, 9(1), 31-51.

Wernerfelt, B. (1995). The resource-based view of the firm: Ten years after. Strategic Management Journal, 16, 171-174.

Winter, S. G. (2003). Understanding dynamic capabilities. Strategic Management Journal, 24, 991995.

Zaichkowsky, J. L. (1985). Measuring the involvement construct. Journal of Consumer Research, 12, 341-352.

Zollo, M., \& Winter, S. G. (2002). Deliberate learning and the evolution of dynamic capabilities. Organization Science, 13, 339-351. 
Table 1: Main definitions

\begin{tabular}{|c|c|c|c|}
\hline \multicolumn{4}{|c|}{ LEVELS OF CAPABILITIES } \\
\hline CONCEPTS & DEFINITIONS & SOURCES & EXAMPLES \\
\hline \multirow[t]{6}{*}{$\begin{array}{l}\text { Dynamic } \\
\text { capability }\end{array}$} & $\begin{array}{l}\text { "Specific strategic and organizational processes like product development, alliancing and strategic decision making that create value for firms } \\
\text { within dynamic markets by manipulating resources into new value-creating strategies". }\end{array}$ & $\begin{array}{l}\text { Eisenhardt \& } \\
\text { Martin (2000, p. } \\
1106)\end{array}$ & \\
\hline & $\begin{array}{l}\text { "A dynamic capability is a learned and stable pattern of collective activity through which the organization systematically generates and modifies } \\
\text { its operating routines in pursuit of improved effectiveness". }\end{array}$ & $\begin{array}{l}\text { Zollo \& Winter } \\
(2002, \text { p. 340) }\end{array}$ & \\
\hline & Dynamic capabilities "operate to extend, modify or create ordinary capabilities". & $\begin{array}{l}\text { Winter }(2003, p . \\
991)\end{array}$ & \\
\hline & "The capacity of an organization to purposefully create, extend or modify its resource base", where resources include assets as well as capabilities. & $\begin{array}{l}\text { Helfat et al. (2007, } \\
\text { p. } 4 \text { ) }\end{array}$ & \\
\hline & $\begin{array}{l}\text { Dynamic capabilities are "the capacity (1) to sense and shape opportunities and threats, }(2) \text { to seize opportunities, and (3) to maintain } \\
\text { competitiveness through enhancing, combining, protecting, and, when necessary, reconfiguring the business enterprise's intangible and tangible } \\
\text { assets". }\end{array}$ & $\begin{array}{l}\text { Teece (2007, p. } \\
\text { 1319) }\end{array}$ & \\
\hline & Defined as "the capacity of an organization to purposefully create, extend, or modify its resource base". & $\begin{array}{l}\text { Helfat et al. (2007, } \\
\text { p. 4) }\end{array}$ & \\
\hline \multirow{4}{*}{$\begin{array}{l}\text { Dynamic } \\
\text { learning } \\
\text { capability }\end{array}$} & $\begin{array}{l}\text { Refer to Collis's (1994) metaphysical, creative, and learning ability, as they focus on creating new capabilities to impact firm outputs and } \\
\text { performance. }\end{array}$ & Hine et al. (2014) & \multirow{4}{*}{$\begin{array}{l}\text { The ability to } \\
\text { interpret } \\
\text { changing market } \\
\text { demand for } \\
\text { products or } \\
\text { services and } \\
\text { adjust the } \\
\text { strategic } \\
\text { direction of the } \\
\text { firm as a result. }\end{array}$} \\
\hline & Act as coordination, learning, and strategic competitive response activities. & $\begin{array}{l}\text { Protogerou, } \\
\text { Caloghirou, \& } \\
\text { Lioukas (2012) }\end{array}$ & \\
\hline & Enable firms to build and renew resources to change how it responds to market demands. & Teece (2014) & \\
\hline & Involve adding new routines and resources through creativity and innovation. & Hine et al. (2014) & \\
\hline \multirow[t]{2}{*}{$\begin{array}{l}\text { Dynamic } \\
\text { functional } \\
\text { capability }\end{array}$} & $\begin{array}{l}\text { Also change focused, but directly responsible for firm outputs and performance in dynamic environments. They are created by learning } \\
\text { mechanisms, which suggests they are lower in the capability hierarchy than DLCs. }\end{array}$ & $\begin{array}{l}\text { Collis (1994) } \\
\text { Hine et al. (2014) }\end{array}$ & \multirow{2}{*}{$\begin{array}{l}\text { The ability to } \\
\text { develop and } \\
\text { implement an } \\
\text { export strategy } \\
\text { (internationalizat } \\
\text { ion functional } \\
\text { capability). }\end{array}$} \\
\hline & $\begin{array}{l}\text { Either marketing or technological capabilities, where marketing capabilities focus on product and service development, pricing, and market- } \\
\text { information management, and technological capabilities focus on increasing efficiency in R\&D and manufacturing processes. }\end{array}$ & $\begin{array}{l}\text { Ellonen et al. (2011) } \\
\text { Protogerou et al. } \\
\text { (2012) }\end{array}$ & \\
\hline \multirow{3}{*}{$\begin{array}{l}\text { Operational } \\
\text { (ordinary) } \\
\text { capability }\end{array}$} & $\begin{array}{l}\text { Non-change focused capabilities responsible for firm outputs without directly contributing to competitive advantage. Enable a firm to make a } \\
\text { living. }\end{array}$ & $\begin{array}{l}\text { Collis (1994); } \\
\text { Winter (2003) }\end{array}$ & \multirow{3}{*}{$\begin{array}{l}\text { Capabilities such } \\
\text { as maintenance } \\
\text { of production } \\
\text { lines or hiring } \\
\text { staff. }\end{array}$} \\
\hline & "The performance of administrative, operational and governance-related functions that are (technically) necessary to accomplish tasks". & $\begin{array}{l}\text { Teece }(2014, p . \\
328)\end{array}$ & \\
\hline & Changes in the efficiency and effectiveness of current business activities. & $\begin{array}{l}\text { Drnevich \& } \\
\text { Kriauciunas (2011) }\end{array}$ & \\
\hline
\end{tabular}


Table 2: Scale development process-Concepts to items (italics added)

\begin{tabular}{|c|c|c|c|c|c|c|c|}
\hline \multirow{3}{*}{ CONCEPTS } & \multirow{2}{*}{\multicolumn{2}{|c|}{$\begin{array}{c}\text { STEP } 1 \\
\text { LITERATURE REVIEW }\end{array}$}} & \multicolumn{2}{|c|}{ STEPS 2 AND 3} & \multirow{3}{*}{$\begin{array}{c}\text { STEP } 4 \\
\begin{array}{c}\text { FINAL SCALES FOR } \\
\text { SURVEY }\end{array} \\
\text { SCALE ITEMS }\end{array}$} & \multirow{2}{*}{\multicolumn{2}{|c|}{$\begin{array}{c}\text { STEP } 5 \\
\text { SURVEY AND ANALYSIS }\end{array}$}} \\
\hline & & & INTERVIEWS AND EXPERT O & NION & & & \\
\hline & DEFINITIONS & SOURCES & QUOTES & THEMES & & FINAL ITEMS & $\begin{array}{c}\text { FINAL } \\
\text { CONSTRUCTS }\end{array}$ \\
\hline $\begin{array}{l}\text { Predomi- } \\
\text { nant } \\
\text { resources }\end{array}$ & $\begin{array}{l}\text { The predominant resources that } \\
\text { underpin capabilities can be } \\
\text { measured on a continuum } \\
\text { ranging from general to highly } \\
\text { specialized. At one end a } \\
\text { resource may be general in its } \\
\text { application and usability, such } \\
\text { as standard desktop computers, } \\
\text { shovels, or accounting journal } \\
\text { entries. At the other end are } \\
\text { highly specialized resources } \\
\text { (Mosakowski, 1993) }\end{array}$ & $\begin{array}{l}\text { Hine et al. } \\
\text { (2014) } \\
\text { Helfat et al. } \\
\text { (2007) }\end{array}$ & $\begin{array}{l}\text { 'It was good then, especially with this training, to be } \\
\text { able to say - okay, well, you've got all your points } \\
\text { you can put them on your map but you can use that } \\
\text { data and interpret it or use it as a planning tool to } \\
\text { do a number of other things.' (GU003) } \\
\text { 'So, it's just, I suppose, a never-ending cycle and } \\
\text { then I suppose, from the higher levels, it's looking at } \\
\text { - is there other technology or machinery or } \\
\text { equipment that we're constantly looking at, } \\
\text { attending shows and exhibitions and so on for } \\
\text { machinery, to see what else we can also bring in to } \\
\text { improve that processes.' (MUO15) } \\
\text { 'Whereas ours is very, very different every day and } \\
\text { same with the skills of our blokes so certain jobs can } \\
\text { only go to certain guys to make sure the job gets } \\
\text { done in the right time.' (MU011) } \\
\text { 'If we're not working on our people, and the skills of } \\
\text { our people, then it'll all wash away, I suppose, over } \\
\text { time.' (MU015) } \\
\text { 'We live not in the high tech, in the mid tech space. } \\
\text { Well it is high tech once you get into it in different } \\
\text { areas.' (MU026) } \\
\text { 'The other examples are with the equipment. We've } \\
\text { up scaled some of our equipment; we're using more } \\
\text { sophisticated plant and equipment for some of the } \\
\text { jobs. Some work we may have outsourced in the } \\
\text { past, we've now purchased equipment and } \\
\text { recruited skilled labor using this more advanced } \\
\text { equipment which allows us to do some of these } \\
\text { things that we would have traditionally outsourced.' } \\
\text { (MU016) }\end{array}$ & $\begin{array}{l}\text { 24. Sophisticated } \\
\text { technology } \\
\text { 21. } 27 / 8 \text {. Different } \\
\text { resource } \\
\text { 23. Expertise }\end{array}$ & $\begin{array}{l}\text { 21. Our resources are } \\
\text { different from those of } \\
\text { our competitors } \\
22 \text {. We employ } \\
\text { specialized technologies } \\
\text { 23. Most tasks in our } \\
\text { enterprise require } \\
\text { extensive expertise to } \\
\text { complete } \\
\text { 24. The technologies we } \\
\text { employ are sophisticated } \\
\text { 25. The most important } \\
\text { knowledge in our } \\
\text { enterprise cannot be } \\
\text { written down } \\
\text { 26. Our activities are } \\
\text { focused on our strategic } \\
\text { resources } \\
\text { 27. Our firm focuses on } \\
\text { gaining new resources } \\
\text { 28. We do not follow our } \\
\text { competitors when } \\
\text { making decisions about } \\
\text { resource acquisitions }\end{array}$ & $\begin{array}{l}\text { 38. Our current } \\
\text { resource base } \\
\text { supports our long- } \\
\text { term } \\
\text { competitiveness } \\
36 . \text { Our staff is } \\
\text { constantly looking } \\
\text { to improve their } \\
\text { practices } \\
26 . \text { Our activities } \\
\text { are focused on our } \\
\text { strategic resources } \\
\text { 39. We have } \\
\text { practices focused } \\
\text { on sustainable } \\
\text { competitiveness }\end{array}$ & $\begin{array}{l}\text { Resource } \\
\text { sustainability } \\
\text { (Williamson \& } \\
\text { Winter, 1993; } \\
\text { Grant 1996) }\end{array}$ \\
\hline
\end{tabular}




\begin{tabular}{|c|c|c|c|c|c|c|c|}
\hline $\begin{array}{l}\text { Patterns - } \\
\text { low to high } \\
\text { repetition }\end{array}$ & $\begin{array}{l}\text { Patterning refers to the } \\
\text { frequency and repetition with } \\
\text { which a behavior occurs, or a } \\
\text { firm evokes a routine and has } \\
\text { received much attention in the } \\
\text { literature. } \\
\text { "Regular and predictable } \\
\text { behavioral patterns of firms." } \\
\text { There are three levels of } \\
\text { routines based on (i) what a } \\
\text { firm does at any given time } \\
\text { given its stock of equipment and } \\
\text { other production factors; (ii) the } \\
\text { period by period augmentation } \\
\text { of equipment and production } \\
\text { factors; and (iii) modification of } \\
\text { operating characteristics and } \\
\text { routines }\end{array}$ & $\begin{array}{c}\text { Nelson \& } \\
\text { Winter } \\
(1982: 14)\end{array}$ & $\begin{array}{l}\text { 'I changed and I formally documented my } \\
\text { development process to start with. Before it was a } \\
\text { bit ad hoc, it happened or it didn't happen. Now I } \\
\text { know what steps.' (IU024) } \\
\text { 'Certainly my skills have expanded in terms of } \\
\text { having to relate processes that are designed around } \\
\text { fairly repetitive tasks to far more flexible } \\
\text { environments. You learn the people skills and } \\
\text { obviously the dealing with workplace conflict and } \\
\text { negotiation and various other HR related skills } \\
\text { through interaction with people.' (MIO03) } \\
\text { 'I just speak to other people about what it is we've } \\
\text { learned through [ ] and how we look at the system } \\
\text { of what we're doing and how I stand back a bit more } \\
\text { now and sort of look at it - maybe we should look at } \\
\text { this and look at it from more angles than I used to.' } \\
\text { (MU021) } \\
\text { '[...] is you learn something. You capture it somehow } \\
\text { and then reapply it when you go to do the same } \\
\text { thing. I think we're still struggling with that, as an } \\
\text { organization, to do that, as every organization is. } \\
\text { But I think it comes about when you put processes } \\
\text { in place.' (GI002) } \\
\text { '[...] like I said everything is in a few people's heads } \\
\text { and we don't have a very good structure around it.' } \\
\text { (MU020) } \\
\text { 'We're just in the rhythm of constantly improving it } \\
\text { every way we can. And I tell you, you have to at the } \\
\text { moment.' (MU006) }\end{array}$ & $\begin{array}{l}\text { 29. Adaptive } \\
\text { activity } \\
\text { 35. Refocus } \\
\text { approach } \\
\text { 36. Routinization }\end{array}$ & $\begin{array}{l}\text { 29. Activities needed to } \\
\text { be successful in our } \\
\text { market are always } \\
\text { changing } \\
\text { 30. Typical tasks in our } \\
\text { enterprise are low } \\
\text { repetition tasks } \\
\text { 31. Staff have flexibility } \\
\text { in how they fulfil their } \\
\text { roles } \\
\text { 32. There are few } \\
\text { standard practices that } \\
\text { new staff can follow } \\
\text { when they join our firm } \\
\text { 33. The majority of tasks } \\
\text { undertaken in our firm } \\
\text { cannot be captured in } \\
\text { manuals } \\
\text { 34. We are always } \\
\text { changing our practices in } \\
\text { our enterprise } \\
\text { 35. Our competitiveness } \\
\text { depends on constant } \\
\text { change to our processes } \\
\text { and resources in the } \\
\text { future } \\
\text { 36. Our staff are } \\
\text { constantly looking to } \\
\text { improve practices }\end{array}$ & $\begin{array}{l}\text { 33. The majority of } \\
\text { tasks undertaken } \\
\text { in our firm cannot } \\
\text { be captured in } \\
\text { manuals } \\
25 \text {. The most } \\
\text { important } \\
\text { knowledge in our } \\
\text { firm cannot be } \\
\text { written down } \\
32 \text {. There are few } \\
\text { standard practices } \\
\text { for new staff to } \\
\text { follow when they } \\
\text { join our firm. }\end{array}$ & $\begin{array}{l}\text { Low } \\
\text { repetition } \\
\text { patterning } \\
\text { (Teece, } 2007 \\
\text { Zollo \& } \\
\text { Winter, } 2002 \\
\text { Van Den } \\
\text { Bosch \& } \\
\text { Volberda, } \\
\text { 2006) }\end{array}$ \\
\hline $\begin{array}{c}\text { Compe- } \\
\text { titive } \\
\text { (strategic) } \\
\text { intent }\end{array}$ & $\begin{array}{l}\text { "Companies that have risen to } \\
\text { global leadership over the past } \\
20 \text { years invariably began with } \\
\text { ambitions that were out of all } \\
\text { proportion to their resources } \\
\text { and capabilities. But they } \\
\text { created an obsession with } \\
\text { winning at all levels of the } \\
\text { organization and then sustained } \\
\text { that obsession over the 10- to } \\
\text { 20-year quest for global } \\
\text { leadership. We term this } \\
\text { obsession strategic intent" (p. } \\
\text { 64). }\end{array}$ & $\begin{array}{c}\text { Hamel \& } \\
\text { Prahalad } \\
\text { (1989) }\end{array}$ & $\begin{array}{l}\text { 'I think it's been a continuous process or a journey, } \\
\text { if you like, ever since because whilst the [...] was a } \\
\text { great introduction, we've gone a long way down } \\
\text { that road now and we're still learning. We've been } \\
\text { able to develop, I suppose, down different roads to } \\
\text { check whether or not there was relevancy. We've } \\
\text { been up quite a few dry creeks, let me tell you, but } \\
\text { we needed to do that as far as our overall } \\
\text { development.' (IU014) } \\
\text { 'it's a competitive marketplace, and if we're not } \\
\text { implementing these sort of processes, we're finding } \\
\text { that the market - whoever happens to be the } \\
\text { market leader is already ahead of the game and } \\
\text { already implementing these sort of strategies, and } \\
\text { so if you're not interested in taking the ideas up or }\end{array}$ & $\begin{array}{l}\text { 37. 38. Upward } \\
\text { trajectory }\end{array}$ & $\begin{array}{l}\text { 37. We seek to lead in } \\
\text { our markets } \\
38 \text {. Our current resource } \\
\text { base supports our long- } \\
\text { term competitiveness. } \\
\text { 39. We have practices } \\
\text { focused on sustainable } \\
\text { competitiveness } \\
\text { 40. Our most important } \\
\text { activities are those that } \\
\text { create future } \\
\text { opportunities } \\
\text { 41. We are always } \\
\text { seeking new markets and } \\
\text { new market positions. }\end{array}$ & $\begin{array}{l}\text { 35. Our } \\
\text { competitiveness } \\
\text { depends on } \\
\text { constant change to } \\
\text { our processes and } \\
\text { resources } \\
\text { 43. We change the } \\
\text { rules of } \\
\text { competition in our } \\
\text { market } \\
\text { 29. Activities to be } \\
\text { successful in our } \\
\text { market are always } \\
\text { changing }\end{array}$ & $\begin{array}{l}\text { Change } \\
\text { intent } \\
\text { (Winter, 2003 } \\
\text { Zollo \& } \\
\text { Winter, 2002) }\end{array}$ \\
\hline
\end{tabular}




\begin{tabular}{|c|c|c|c|c|c|c|c|}
\hline & $\begin{array}{l}\text { Match and even create market } \\
\text { change. }\end{array}$ & $\begin{array}{c}\text { Eisenhardt } \\
\text { \& Martin } \\
(2000)\end{array}$ & $\begin{array}{l}\text { taking the technology up, you're going to get left } \\
\text { behind, and you're not going to have a successful } \\
\text { business for too much longer if you're not really } \\
\text { willing to change and grasp things.' (MU015) } \\
\text { 'There's this constant step. There's this little ramp } \\
\text { which goes from the current to the better, but then } \\
\text { flattens out to another step and then there's } \\
\text { another ramp. It's just constant.' (MU017) } \\
\text { 'And that's really opened up everyone's minds to } \\
\text { the fact that they change is a good thing because it's } \\
\text { going to improve us, make us sustainable, those } \\
\text { sorts of things.' (MUO04) } \\
\text { 'We were just going day by day...I thought I knew } \\
\text { what was happening, but it wasn't. We didn't have } \\
\text { any plan, didn't have any structure, didn't have any } \\
\text { system orientation and I suppose the biggest thing } \\
\text { that I got out of it was to plan, to budget, to } \\
\text { systemize and to utilize people that knew what they } \\
\text { were doing instead of just taking on friends.' (IU006) }\end{array}$ & $\begin{array}{l}\text { 34. Staying ahead } \\
\text { 35. } 36 \text {. } \\
\text { Sustainability } \\
\text { 37. } 38 \text {. Chasing } \\
\text { opportunity }\end{array}$ & $\begin{array}{l}\text { 42. We move first in our } \\
\text { market } \\
43 \text {. We change the rules } \\
\text { of competition in our } \\
\text { market }\end{array}$ & $\begin{array}{l}\text { 34. We are always } \\
\text { changing our } \\
\text { practices in our } \\
\text { firm } \\
40 . \text { Our most } \\
\text { important } \\
\text { activities are those } \\
\text { that create future } \\
\text { opportunities }\end{array}$ & \\
\hline $\begin{array}{l}\text { Focus of } \\
\text { learning } \\
\text { tasks: } \\
\text { explora- } \\
\text { tive }\end{array}$ & $\begin{array}{l}\text { Exploration learning activities } \\
\text { are associated with variation, } \\
\text { scanning, creativity, path- } \\
\text { breaking, and recombination, } \\
\text { whereas exploitation learning } \\
\text { activities are associated with } \\
\text { selection, adaptation, } \\
\text { routinization, and structures }\end{array}$ & $\begin{array}{l}\text { Zollo \& } \\
\text { Winter } \\
\text { (2002); He } \\
\text { \& Wong } \\
\text { (2004); } \\
\text { Lavie, } \\
\text { Stettner, \& } \\
\text { Tushman } \\
\text { (2010) }\end{array}$ & $\begin{array}{l}\text { 'We got new tools to track down the efficiencies of } \\
\text { our tools. We got new tools, how to actually chew } \\
\text { down the big problem into small pieces, so where to } \\
\text { go next, how to make the items that the operators } \\
\text { needed to do, how to make it visual...but [...] clearly } \\
\text { gave us new ideas what to include into TPM project. } \\
\text { Like operators follow-up their accident, are tracking } \\
\text { down every day, every shift how the line is running. } \\
\text { Earlier they didn't do any of that, so actually take } \\
\text { that on time, follow-up into the equation as well.' } \\
\text { (MU003) } \\
\text { 'The other things were issues such as IP and } \\
\text { trademarks and patents, which is a difficult one in } \\
\text { our industry because technology's moving so fast, } \\
\text { by the time you've tried to patent it all, it's moved } \\
\text { on.' (IU001) } \\
\text { 'Obviously we hadn't done a good job of filtering the } \\
\text { knowledge down through the business, so from that } \\
\text { perspective, the second time around, we've } \\
\text { managed to filter the knowledge a lot broader } \\
\text { through the business.' (MU015) } \\
\text { '[...] really only gave us some contacts in the robotic } \\
\text { welding. Basically you have to make a decision and } \\
\text { learn yourself... they probably helped convince us } \\
\text { that it was a good idea, but really, no. We had to } \\
\text { start from scratch with the robot and go out and } \\
\text { find the knowledge, find the suppliers.' (MU014) }\end{array}$ & 2. 8. New ideas & $\begin{array}{l}\text { 1. We frequently utilize } \\
\text { new opportunities in } \\
\text { new markets } \\
\text { 2. New opportunities to } \\
\text { serve our customers with } \\
\text { existing technologies are } \\
\text { quickly captured } \\
\text { 3. Our firm regularly uses } \\
\text { new distribution } \\
\text { channels } \\
\text { 4. We experiment with } \\
\text { new products and } \\
\text { services in our market } \\
\text { 5. We quickly interpret } \\
\text { changing market } \\
\text { demand for our } \\
\text { products/services } \\
\text { 6. We regularly search } \\
\text { for and approach new } \\
\text { clients in new markets } \\
\text { 7. Our firm accepts } \\
\text { demands that go beyond } \\
\text { existing } \\
\text { products/services } \\
\text { 8. We invent new } \\
\text { products/services }\end{array}$ & $\begin{array}{l}\text { 1. We frequently } \\
\text { utilize new } \\
\text { opportunities in } \\
\text { new markets } \\
\text { 4. We experiment } \\
\text { with new products } \\
\text { and services in our } \\
\text { market } \\
5 . \text { We quickly } \\
\text { interpret changing } \\
\text { market demand } \\
\text { for our } \\
\text { products/services } \\
\text { 8. We invent new } \\
\text { products/services }\end{array}$ & $\begin{array}{l}\text { Exploration } \\
\text { (Adapted } \\
\text { from: Jansen } \\
\text { et al. 2006) }\end{array}$ \\
\hline
\end{tabular}




\begin{tabular}{|c|c|c|c|c|c|c|c|}
\hline & & & $\begin{array}{l}\text { 'The whole idea of branding. That I had before I } \\
\text { started the business but it was reinforced by this so } \\
\text { that's what I'm trying to do, build that brand. I want } \\
\text { to become a knowledge guru, so a point of source } \\
\text { for people wanting practical operational sort of } \\
\text { advice as well as projects.' (IU001) } \\
\text { 'It has been a very hands-on project in terms of it } \\
\text { hasn't been anything that somebody has been } \\
\text { analyzing some data behind the doors. It's been very } \\
\text { hands-on with the operators.' (MU003) }\end{array}$ & $\begin{array}{l}\text { 4. } 5.8 . \\
\text { Knowledge }\end{array}$ & & & \\
\hline $\begin{array}{l}\text { Focus of } \\
\text { learning } \\
\text { tasks: } \\
\text { exploita- } \\
\text { tive }\end{array}$ & $\begin{array}{l}\text { Exploration is what we often } \\
\text { recognize as innovation: firms } \\
\text { seek out new alternatives to } \\
\text { respond to new and future } \\
\text { challenges and create new } \\
\text { opportunities. Exploitation is } \\
\text { recognized as consistency: firms } \\
\text { excelling in their current } \\
\text { opportunities (March, 1991). }\end{array}$ & $\begin{array}{l}\text { Jansen et } \\
\text { al. (2006) } \\
\text { March } \\
\text { (1991) }\end{array}$ & $\begin{array}{l}\text { 'Oh gee whiz I just seem to always have it (the GIS } \\
\text { software) going. ... So for me personally being able } \\
\text { to access that technology has just... Planning, } \\
\text { planning. Like forward. I'm talking about just your; } \\
\text { almost to go to the ridiculous is your dreams and } \\
\text { your aspirations and you can sort of just think and } \\
\text { adjust.' (GU011) } \\
\text { 'If you wanted to really sum it up and therefore we } \\
\text { have to continually change the way we do things, } \\
\text { refine the way we do things, improve our processes } \\
\text { if we are going to remain viable in the future.' } \\
\text { (MU004) } \\
\text { 'So from that perspective, we've virtually got a } \\
\text { month by month improvement program going on to } \\
\text { evolve and change and further develop the } \\
\text { processes that we already have.' (MU015) } \\
\text { 'We established ourselves as a current view of the } \\
\text { situation. We applied some of this knowledge, } \\
\text { which then took us to a better view of the situation. } \\
\text { What we've discovered is, by doing all these things, } \\
\text { the better view of the situation then becomes the } \\
\text { current. Because we have a lot of minds working on } \\
\text { the whole system, that new current view moves into } \\
\text { another better view.' (MU017) }\end{array}$ & $\begin{array}{l}\text { 9. Refinement } \\
\text { 11. } 12 . \\
\text { Adaptation } \\
\text { 13. Improve } \\
\text { 16. Scale } \\
\text { 17. Expand } \\
\text { 14. 15. More } \\
\text { efficient }\end{array}$ & $\begin{array}{l}\text { 9. We frequently seek to } \\
\text { refine the provision of } \\
\text { existing } \\
\text { processes/services } \\
\text { 10. Our employees } \\
\text { capture knowledge for } \\
\text { our firm's future use } \\
11 \text {. We regularly } \\
\text { implement small } \\
\text { adaptations to existing } \\
\text { products/services } \\
12 . \text { We are proficient at } \\
\text { applying existing } \\
\text { knowledge to new uses } \\
\text { 13. We seek to introduce } \\
\text { improved, but existing } \\
\text { products/services for our } \\
\text { market } \\
14 \text {. We capture relevant } \\
\text { knowledge for re-use } \\
\text { over time. } \\
15 \text {. We seek to improve } \\
\text { our firm's efficiency at } \\
\text { providing existing } \\
\text { products/services } \\
16 \text {. We seek to achieve } \\
\text { economies of scale in } \\
\text { existing markets } \\
17 . \text { We communicate } \\
\text { relevant knowledge } \\
\text { across the different parts } \\
\text { of our firm. } \\
18 . \text { When recognizing a } \\
\text { business opportunity, we } \\
\text { can quickly rely on our } \\
\text { existing knowledge }\end{array}$ & $\begin{array}{l}\text { 2. New } \\
\text { opportunities to } \\
\text { serve our } \\
\text { customers with } \\
\text { existing } \\
\text { technologies are } \\
\text { quickly captured } \\
\text { 10. Our employees } \\
\text { capture knowledge } \\
\text { for our firm's } \\
\text { future use } \\
\text { 11. We regularly } \\
\text { implement small } \\
\text { adaptations to } \\
\text { existing } \\
\text { products/services } \\
\text { 12. We are } \\
\text { proficient at } \\
\text { applying existing } \\
\text { knowledge to new } \\
\text { uses } \\
\text { 13. We seek to } \\
\text { introduce } \\
\text { improved, but } \\
\text { existing } \\
\text { products/services } \\
\text { for our market } \\
\text { 14. We capture } \\
\text { relevant } \\
\text { knowledge for re- } \\
\text { use over time }\end{array}$ & $\begin{array}{l}\text { Exploitation } \\
\text { (Adapted } \\
\text { from: Jansen } \\
\text { et al. 2006) }\end{array}$ \\
\hline
\end{tabular}




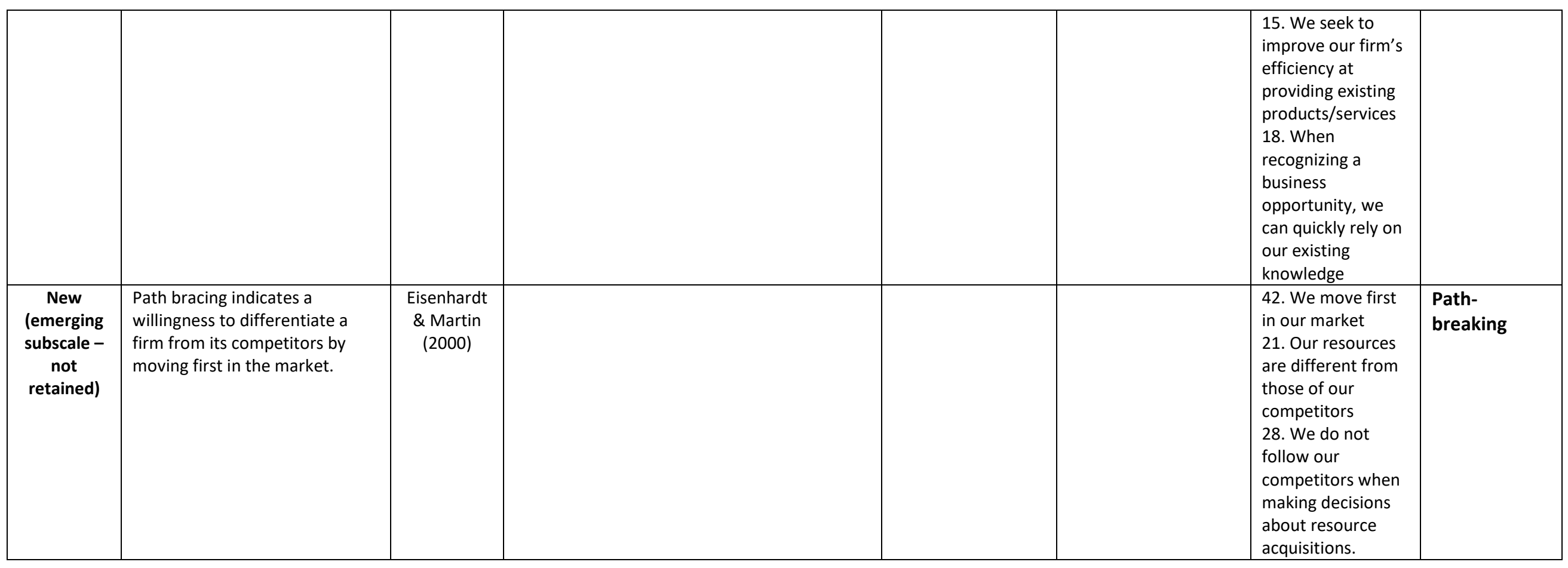


Table 3: Scale unidimensionality and reliability analysis

\begin{tabular}{lllllll}
\hline \hline Construct scale & $\begin{array}{l}\text { Number } \\
\text { of items }\end{array}$ & RMSEA & $\chi^{2} / \mathrm{DF}$ & $\mathrm{p}$ & $\mathrm{CFI}$ & $\mathrm{GFI}$ \\
\hline Low Repetition Patterning & 3 & .061 & 3.22 & .073 & .985 & .996 \\
Change intent & 5 & .041 & 1.985 & .077 & .987 & .994 \\
Resource sustainability & 4 & .012 & 1.092 & .335 & 1.00 & .998 \\
Path Breaking & 3 & .000 & .001 & .972 & 1.00 & 1.00 \\
Exploitation & 8 & .020 & 1.233 & .215 & 1.00 & .990 \\
Exploration & 4 & .073 & 4.165 & .016 & .983 & .993 \\
\hline \hline
\end{tabular}


Table 4: Means, standard deviations, and correlations (final 15 items of the proposed DLCs scale)

\begin{tabular}{|c|c|c|c|c|c|c|c|c|c|c|c|c|c|c|c|c|}
\hline & Mean & SD & LRP1 & LRP2 & LRP3 & $\mathrm{Cl} 1$ & $\mathrm{Cl} 2$ & $\mathrm{Cl} 3$ & $\mathrm{Cl} 4$ & $\mathrm{Cl} 5$ & RS1 & RS2 & RS3 & RS4 & PB1 & PB2 \\
\hline $\begin{array}{l}\text { LRP1 The majority of tasks } \\
\text { undertaken in our firm cannot be } \\
\text { captured in manuals }\end{array}$ & 3.027 & 1.205 & & & & & & & & & & & & & & \\
\hline $\begin{array}{l}\text { LRP2 The most important knowledge } \\
\text { in our firm cannot be written down }\end{array}$ & 3.355 & 1.246 & $.419 * *$ & & & & & & & & & & & & & \\
\hline $\begin{array}{l}\text { LRP3 There are few standard } \\
\text { practices for new staff to follow when } \\
\text { they join our firm }\end{array}$ & 2.98 & 1.362 & $.157^{* *}$ & $.229 * *$ & & & & & & & & & & & & \\
\hline $\begin{array}{l}\mathrm{Cl} 1 \text { Our competitiveness depends on } \\
\text { constant change to our processes and } \\
\text { resources }\end{array}$ & 3.417 & 1.096 & 0.004 & 0.069 & $.101 *$ & & & & & & & & & & & \\
\hline $\begin{array}{l}\mathrm{Cl} 2 \text { We are always changing our } \\
\text { practices in our firm }\end{array}$ & 3.205 & 1.032 & 0.06 & 0.038 & -0.008 & $.287^{* *}$ & & & & & & & & & & \\
\hline $\begin{array}{l}\mathrm{Cl} 3 \text { Activities needed to be successful } \\
\text { in our market are always changing }\end{array}$ & 3.563 & 0.9717 & $.163^{* *}$ & $.207 * *$ & $.112^{* *}$ & $.408 * *$ & $.273^{* *}$ & & & & & & & & & \\
\hline $\begin{array}{l}\mathrm{Cl} 4 \text { We change the rules of } \\
\text { competition in our market } \\
\mathrm{Cl} 5 \text { Our most important activities are } \\
\text { those that create future }\end{array}$ & 2.812 & 1.181 & 0.055 & 0.066 & 0.06 & $.214^{* *}$ & $.206 * *$ & $.296 * *$ & & & & & & & & \\
\hline opportunities & 3.745 & 1.004 & 0.03 & $.141^{* *}$ & $.115^{* *}$ & $.379 * *$ & $.196 * *$ & $.317 * *$ & $.241^{* *}$ & & & & & & & \\
\hline $\begin{array}{l}\text { RS1 Our activities are focused on our } \\
\text { strategic resources }\end{array}$ & 3.698 & 0.8729 & 0.027 & 0.054 & 0.029 & $.280^{* *}$ & $.200 * *$ & $.340 * *$ & $.170 * *$ & $.337 * *$ & & & & & & \\
\hline $\begin{array}{l}\text { RS2 Our staff seek to constantly } \\
\text { improve their practices }\end{array}$ & 3.932 & 0.8708 & $.166^{* *}$ & $.155^{* *}$ & $.097 *$ & $.276 * *$ & $.218^{* *}$ & $.314 * *$ & $.112 * *$ & $.278 * *$ & $.421 * *$ & & & & & \\
\hline $\begin{array}{l}\text { sustainable competitiveness } \\
\text { RS4 Our current resource base } \\
\text { supports our long-term }\end{array}$ & 3.707 & 0.934 & 0.065 & 0.052 & -0.035 & $.235^{* *}$ & $.180^{* *}$ & $.210^{* *}$ & 0.05 & $.318^{* *}$ & $.342 * *$ & $.341 * *$ & & & & \\
\hline competitiveness & 3.912 & 0.88 & $.130^{* *}$ & $.108^{* *}$ & $.121 * *$ & $.237 * *$ & $.154^{* *}$ & $.314^{* *}$ & $.133^{* *}$ & $.217^{* *}$ & $.454^{* *}$ & $.543 * *$ & $.329 * *$ & & & \\
\hline $\begin{array}{l}\text { PB1 Our resources are different from } \\
\text { those of our competitors }\end{array}$ & 2.971 & 1.25 & $.171 * *$ & $.163 * *$ & 0.076 & 0.065 & $.235^{* *}$ & $.188^{* *}$ & $.182 * *$ & $.127 * *$ & $.111^{* *}$ & $.194 * *$ & $.107 * *$ & $.116^{* *}$ & & \\
\hline $\begin{array}{l}\text { PB2 We don't follow our competitors } \\
\text { when making decisions about }\end{array}$ & & & & & & & & & & & & & & & & \\
\hline $\begin{array}{l}\text { resource acquisitions } \\
\text { PB3 We move first in our market }\end{array}$ & $\begin{array}{l}3.737 \\
3.388\end{array}$ & $\begin{array}{l}1.058 \\
1.042\end{array}$ & $\begin{array}{l}.212^{* *} \\
.090^{*}\end{array}$ & $\begin{array}{l}.151^{* *} \\
0.027\end{array}$ & $\begin{array}{l}.088^{*} \\
0.047\end{array}$ & $\begin{array}{l}0.075 \\
.231^{* *}\end{array}$ & $\begin{array}{l}.112 * * \\
.289 * *\end{array}$ & $\begin{array}{l}.146 * * \\
.232 * *\end{array}$ & $\begin{array}{l}.080^{*} \\
.230 * *\end{array}$ & $\begin{array}{l}.190^{* *} \\
.264^{* *}\end{array}$ & $\begin{array}{l}.230 * * \\
.351 * *\end{array}$ & $\begin{array}{l}.328 * * \\
.390 * *\end{array}$ & $\begin{array}{l}.187^{* *} \\
.272^{* *}\end{array}$ & $\begin{array}{l}.260^{* *} \\
.387^{* *}\end{array}$ & $\begin{array}{l}.275^{* *} \\
.276^{* *}\end{array}$ & $.325 * *$ \\
\hline
\end{tabular}


Table 5: Regression Coefficients (Factor Loadings) and Correlations for Multi-Factor Model

\begin{tabular}{|c|c|c|c|c|}
\hline Construct/Item & $\begin{array}{l}\text { 1. Low } \\
\text { Repetition } \\
\text { Patterning } \\
\text { (LRP) }\end{array}$ & $\begin{array}{l}\text { 2. Change } \\
\text { Intent (Cl) }\end{array}$ & $\begin{array}{l}\text { 3. Resource } \\
\text { Sustainability } \\
\text { (RS) }\end{array}$ & $\begin{array}{l}\text { 4. Path Breaking } \\
\text { (PB) }\end{array}$ \\
\hline LRP1 & 1.00 & & & \\
\hline LRP2 & $\begin{array}{c}1.25 \\
(5.85)\end{array}$ & & & \\
\hline LRP3 & $\begin{array}{c}.61 \\
(5.42)\end{array}$ & & & \\
\hline $\mathrm{Cl} 1$ & & 1.00 & & \\
\hline $\mathrm{Cl} 2$ & & $\begin{array}{c}.68 \\
(8.24)\end{array}$ & & \\
\hline $\mathrm{Cl} 3$ & & $\begin{array}{c}.96 \\
(10.80)\end{array}$ & & \\
\hline $\mathrm{Cl} 4$ & & $\begin{array}{c}.72 \\
(7.69)\end{array}$ & & \\
\hline $\mathrm{Cl} 5$ & & $\begin{array}{c}.87 \\
(10.02)\end{array}$ & & \\
\hline RS1 & & & 1.00 & \\
\hline RS2 & & & $\begin{array}{c}1.13 \\
(13.16)\end{array}$ & \\
\hline RS3 & & & $\begin{array}{c}.86 \\
(10.25)\end{array}$ & \\
\hline RS4 & & & $\begin{array}{c}1.14 \\
(13.12)\end{array}$ & \\
\hline PB1 & & & & 1.00 \\
\hline PB2 & & & & $\begin{array}{c}1.08 \\
(7.03)\end{array}$ \\
\hline PB3 & & & & $\begin{array}{c}1.37 \\
(7.51)\end{array}$ \\
\hline Correlations & 1. & 2. & 3. & 4. \\
\hline $\begin{array}{l}\text { 1. Low } \\
\text { Repetition } \\
\text { Patterning }\end{array}$ & 1.00 & & & \\
\hline 2. Change Intent & .30 & 1.00 & & \\
\hline $\begin{array}{l}\text { 3. Resource } \\
\text { Sustainability }\end{array}$ & .24 & .73 & 1.00 & \\
\hline 4. Path Breaking & .28 & .59 & .67 & 1.00 \\
\hline
\end{tabular}


Table 6: Regression Coefficients (Structural Relationships) for Full Structural Equations Models

\begin{tabular}{llll}
\hline \hline Path & Model 1 & Model 2 & Model 3 \\
\hline Low-Repetition Patterning $\rightarrow$ Financial Performance & .13 & .08 & .08 \\
Path-Breaking Approach $\rightarrow$ Financial Performance & $(2.07)$ & $(1.33)$ & $(1.19)$ \\
& .17 & .18 & .18 \\
Resource Sustainability $\rightarrow$ Financial Performance & $(1.74)$ & $(1.15)$ & $(.92)$ \\
& .55 & .47 & .71 \\
Change Intent $\rightarrow$ Financial Performance & $(5.10)$ & $(3.08)$ & $(2.61)$ \\
& -.10 & -.24 & -.29 \\
Exploitation $\rightarrow$ Financial Performance & $(-1.40)$ & $(-2.38)$ & $(-1.66)$ \\
& .01 & .06 & -.26 \\
Exploration $\rightarrow$ Financial Performance & $(.09)$ & $(.51)$ & $(-1.07)$ \\
& .07 & .10 & .21 \\
Low-Repetition Patterning $\rightarrow$ Customer Performance & $(.10)$ & $(.75)$ & $(.84)$ \\
& .22 & .20 & .18 \\
Path-Breaking Approach $\rightarrow$ Customer Performance & $(3.70)$ & $(3.43)$ & $(2.86)$ \\
& .07 & -.12 & -.05 \\
Resource Sustainability $\rightarrow$ Customer Performance & $(.83)$ & $(-.86)$ & $(-.29)$ \\
& .51 & .50 & .79 \\
Change Intent $\rightarrow$ Customer Performance & $(5.35)$ & $(3.59)$ & $(3.09)$ \\
& .03 & -.01 & .05 \\
Exploitation $\rightarrow$ Customer Performance & $(.44)$ & $(-.07)$ & $(.29)$ \\
& -.06 & .01 & -.32 \\
Exploration $\rightarrow$ Customer Performance & $(-.64)$ & $(.07)$ & $(-1.45)$ \\
& .04 & .03 & -.03 \\
& $(.47)$ & $(.29)$ & $(-.11)$ \\
\hline \hline
\end{tabular}

